\title{
La ocupación tardoantigua de La Cueva de Guantes (Palencia): Contexto y Materiales ${ }^{1}$
}

\section{Late antiquity occupation of the Cave of Guantes (Palencia): Context and materials.}

\author{
Luis R. Menéndez-Bueyes, ${ }^{2}$ \\ Patricia A. Argüelles Álvarez, ${ }^{3}$ \\ Ana Mateos Cachorro, ${ }^{4}$ \\ Jesús Rodríguez Méndez ${ }^{5}$
}

\section{RESUMEN}

La Cueva de Guantes (Palencia), ubicada en las proximidades de Guardo, es un yacimiento conocido por sus depósitos del Paleolítico Medio e indefinidas ocupaciones posteriores. Este estudio da a conocer un conjunto de materiales tardoantiguos entre los que destaca un tremís del rey visigodo Égica, recuperado en los niveles superficiales de la cueva durante las últimas intervenciones arqueológicas. El monetario de época visigoda no es demasiado numeroso y, por ello, siempre resulta de interés darlo a conocer en este contexto arqueológico. Como indicamos, junto a la moneda aparecieron otros materiales que permiten realizar algunas consideraciones sobre las características del hallazgo y del yacimiento. El trabajo realiza un extenso análisis sobre las ocupaciones en cuevas durante los momentos tardíos del Imperio romano y la tardoantigüedad, y sobre el papel que las vías de comunicación romanas pueden haber desempeñado en la ocupación tardía de la Cueva de Guantes. Tras este estudio, se concluye que la cueva debió de ser fruto de ocupaciones puntuales, pero continuadas en el tiempo, debido a su buena ubicación y accesibilidad, y posiblemente en relación con labores agropecuarias. El hallazgo del tremís pudiera ser fruto de una pérdida casual, pero también de una ocultación ante un evento violento, en cuyo caso proponemos el contexto de las cercanas operaciones militares realizadas por los musulmanes entre el 712 y el 713 para el control del norte peninsular.

Palabras clave: Tremís, Égica, Peine, Afiladera, Ocupación en cuevas, Paisaje de la Antigüedad Tardía, Alta Edad Media, Cordillera Cantábrica.

\section{ABSTRACT}

Cave of Guantes, located in Palencia, near the village called Guardo, is a site known for its Middle Paleolithic deposits, as well as for indefinite subsequent occupations. The present study discloses a set of Late Antiquity material, highlighting, among them, a "tremís" that belonged to Visigothic King Égica, which was recovered on the surface levels of the cave, during the last archeological interventions. Because the coins from the Visigothic period are not too numerous, it seems interesting to make them known within this archeological context. As it has been mentioned, along with the coin, some other material appeared which allowed s to make some assumptions about the characteristics of the finding and the deposit. The work includes an extensive analysis on the occupation of the cave during the late times of the Roman Empire and Late Antiquity, as well as on the possible role played

1. Trabajo realizado en el marco del proyecto: Formación y dinámica de los espacios comunales ganaderos en el Noroeste de la Península Ibérica medieval: paisajes e identidades sociales en perspectiva comparada. HAR2016-76094-C4-4-R. Equipo ATAEMHIS, Universidad de Salamanca. Los trabajos de investigación e intervención arqueológica han sido financiados por la Dirección General de Patrimonio de la Junta de Castilla y León, Diputación de Palencia, Ayuntamiento de Santibáñez de la Peña, y por el Centro Nacional de Investigación sobre la Evolución Humana (CENIEH). Los autores quieren mostrar su agradecimiento tanto a los miembros del proyecto de investigación, P. Sevilla, C. Laplana y A. Ollé, como a todos los colaboradores en los trabajos de campo, y a las aportaciones realizadas por los evaluadores del trabajo y, muy especialmente, a las sugerencias de Ruth Pliego. Cualquier error u omisión en el trabajo, así como las opiniones en él expresadas, son únicamente imputables a los autores del mismo.

2. Departamento de Prehistoria, Historia Antigua y Arqueología. Universidad de Salamanca.

3. Departamento de Prehistoria, Historia Antigua y Arqueología. Universidad de Salamanca.

4. Centro Nacional de Investigación sobre la Evolución Humana (CENIEH). Burgos.

5. Centro Nacional de Investigación sobre la Evolución Humana (CENIEH). Burgos. 
by the Roman communication channels during the late occupation of the Cave of Guantes. Our conclusion, after the study, is that the cave must have been the result of exceptional occupations, although continuous over the time, due to its fine location and accessibility, and also probably in relation to agricultural work. The discovery of the "tremís" could be by chance, but also due to an

\section{1.- INTRODUCCIÓN: LA CUEVA}

La cueva de Guantes se localiza entre las localidades de Villanueva de Arriba y Villaoliva de la Peña (Santibáñez de la Peña), cercana a la localidad de Guardo (Palencia). ${ }^{6}$ Forma parte de un complejo kárstico con varios yacimientos que contienen rellenos pertenecientes al Pleistoceno medio y superior situado en las estribaciones de la Sierra del Brezo. El yacimiento, en lo excavado hasta el momento, se muestra como un lugar de hibernación de osos de las cavernas, del que se han localizado muestras importantes, y con al menos tres eventos registrados de ocupación del Paleolítico Medio, asociados a industria lítica neandertal (RODRÍGUEZ y MATEOS, 2014; MATEOS CACHORRO y RODRÍGUEZ MÉNDEZ, 2017 y 2017b). ${ }^{7}$ La Cueva de Guantes presenta dos entradas que se abren en la cara norte y sur de La Loma, respectivamente y, al menos, tres niveles de galerías. Las dos bocas están conectadas por una galería fácilmente transitable, correspondiente al nivel más bajo, de medio kilómetro de largo. Esta galería es recorrida en la actualidad por una canalización de agua (MATEOS CACHORRO et al., 2014). Los materiales aquí presentados se localizaron en la boca sur (Fig. 1). occultation caused by a violent event, in which case we propose, as the reason, the military operations carried out by the Muslims, between year 712 and 713 , to get control over the North of the Península.

Keywords: Tremís, Égica, Comb, Sharpering, Caves occupation, Late Antiquity, High Medieval Age, Cantabrian mountain range area.

\section{2.- OCUPACIÓN DE CUEVAS DURANTE EL PERÍODO TARDORROMANO Y TARDOANTIGUO}

La Cueva de Guantes se encuentra en un entorno de cómodo acceso desde los terrenos de vocación agrícola-ganaderos que se abren a sus mismos pies y que actualmente se dedican a cultivos forrajeros y aprovechamiento maderero de repoblación, en un contexto de extenso páramo y de abundantes bosques de pinos de diferentes especies en la Loma, en las laderas de la cercana Sierra del Brezo.

Es esta accesibilidad (con independencia de los cambios en la morfología de la cueva y en sus entradas durante el Pleistoceno) la que ha permitido que la cueva fuera objeto de uso por parte humana a lo largo de diversos períodos prehistóricos y que, posiblemente en los de época histórica, su uso nunca fuera el de un hábitat continuo sino más bien como un refugio provisional ante las inclemencias del tiempo, para personas y animales, y lugar de almacenaje. Así parece apuntarlo el material encontrado en la cueva perteneciente a diversos momentos cronológicos. ${ }^{8}$

\footnotetext{
6. Se trata de un topónimo resultado del latín fonte > romance guante, donde encontramos un notable reforzamiento articulatorio de consonante inicial. La existencia en la zona palentina, como en otras muchas, de topónimos referidos al agua de una manera no obvia se hace presente en ejemplos como Hontoria del Cerrato, Ampudia y Longil (Ampudia): NIETO BALLESTER, 2000 y 2013. Posiblemente su nombre esté en relación con la cercana ermita de San Pedro de Guantes, que muy probablemente sea la mencionada como parroquia de San Pedro en la documentación bajomedieval (FERNÁNDEZ FLÓREZ, 1984). «San Pedro» es, por otra parte, una de las advocaciones más frecuentes durante la Tardoantigüedad hispana (SALES, 2012: 396-397). Y no podemos olvidar que, además de la obvia referencia a una posible fuente de agua en un lugar en donde esta no es escasa, la relación entre un topónimo relacionado con el agua y un espacio de culto nos lleva a la posible existencia de simbología religiosa vinculada con el agua en sentido extenso, y más concretamente dentro del cristianismo (MARTIN, 2011: 36-52).

7. En la provincia de Palencia también se conocen indicios neandertales en Cueva Corazón, en el complejo del Cañón de la Horadada (DÍEZ MARTín et al, 2011).

8. Se conocen varios hallazgos de tremises en cuevas y minas inactivas, tales como Cueva Foradada (Huesca), Grottes de Montou (Perpignam), Maurcilles-las-Illas (Ceret), Tortella de Montgrí, la cueva-dolmen del Tossal Gross, Sotiel Coronado (Huelva), La Condenada (Cuenca), en Cova del Parco (Alós de Balaguer, Lérida) y en la mina de Los Morceguillos (Alconchel de la Estrella, Cuenca) (PLIEGO, 2009: I, 257; PLIEGO, 2015: 42; ORTEGA, 2018: 94 y 98).
} 


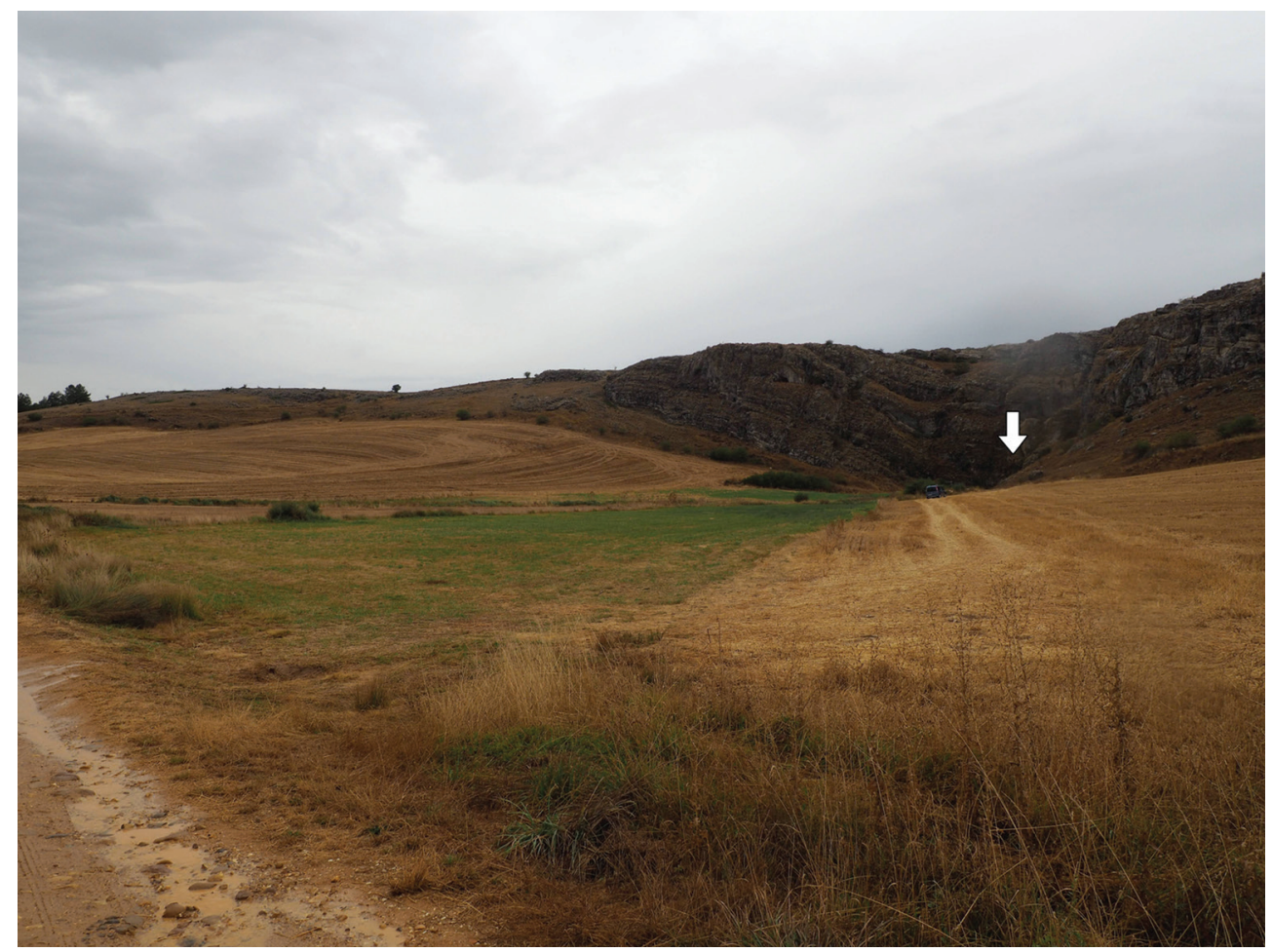

Fig. 1. Cueva de Guantes. Boca Sur.

De la provincia de Palencia se conocen otras ocupaciones tardías puntuales en cueva en la zona de Mave. En concreto del conjunto de la Horadada, de donde proceden tanto un jarrito litúrgico visigótico de bronce como de Cueva Larga, en la que, junto a un pequeño lote de objetos, se inhumaron varias decenas de individuos, de edades bastante repartidas, que se pudieron fechar entre los siglos VI-VII d.C. (DIEGO SANTOS, 1979: 37 y 42; SANTONJA et al, 1982; GUTIÉRREZ GONZÁLEZ, 1982: 35-36). Por otra parte, también en el área de Mave, se documenta la iglesia rupestre tallada en la roca de los Santos Justo y Pastor, vinculada con un enclave eremítico que se suele datar en momentos tardíos del reino toledano (DIEGO SANTOS, 1979: 37; GUTIÉRREZ GONZÁLEZ, 1982: 40-42 Y 49). Aunque este fenómeno de las cuevas artificiales relacionadas con eremitorios e iglesias es más intenso y característico en la zona riojana (LECANDA, 2015; FEIJOÓ, 2018).

Las ocupaciones en cuevas durante el período tardorromano, la Tardoantigüedad y la primera Edad Media es un fenómeno de cierta recurrencia en la Europa occidental $y$, por ende, en los territorios que, en mayor o menor medida, conformaron el Imperio romano (BRANIGAN y DEARNE, 1992; QUIRÓS y ALONSO, 2007-2008: 1123; BERGSVIK y DOWD, 2018). En este sentido, resulta llamativo el hecho de que, en la zona palentina, al igual que ocurre en la Cantabria marítima -pero también en otras muchas áreas geográficas, como el País Vasco o Asturias-, resulta escasa e irrelevante la presencia de restos de época romana, y en menor medida tardorromana, en cuevas naturales, al igual que, por ejemplo, en Cantabria ocurre durante la Edad del Hierro (SMITH y MUÑOZ, 2010; LUIS MARIÑO, 2014), mientras que asistimos a una cierta proliferación del fenómeno durante la Tardoantigüedad (GUTIÉRREZ CUENCA y HIERRO GÁRATE, 2007: 135-136; QUIRÓS y ALONSO, 2007-2008: 1138; FANJUL PERAZA, 2011).

La explicación de este fenómeno se entiende en el presente como multicausal, dependiendo de cronologías y sitios e, incluso, pudiendo variar las motivaciones de uso de las mismas cuevas durante los distintos momentos de su utilización. En cuanto al caso concreto de la península ibérica, aún falta 
un estudio conjunto de todo el fenómeno de la ocupación en cuevas desde época romana que abarque todo el conjunto del territorio español. Sin embargo, igualmente, hemos de tener en cuenta que, en realidad, son muy pocos los lugares en los que realmente existió una continuidad de ocupación desde la Prehistoria, siendo más bien una serie de utilizaciones discontinuas, tal y como evidencia la escasa entidad de los materiales encontrados, que casi nunca conforman un auténtico nivel arqueológico de ocupación. Y, en este sentido, es sumamente significativo el hecho de que las ocupaciones tardorromanas en el norte peninsular no fueron precedidas de un claro uso durante el Alto imperio (ESTEBAN DELGADO, 1990: 338), algo que sí podemos encontrar en otros ámbitos geográficos.

Casos estudiados sobre ocupaciones en cueva en el área vasca proponen desde una prolongación de hábitat prehistórico ${ }^{9}$, hasta reocupaciones durante el siglo $\mathrm{V}$ a consecuencia de los "convulsos" momentos históricos, incluyendo la muy frecuente alusión a eremitorios del cristianismo primitivo (QUIRÓS y ALONSO, 2007-2008; FEIJOÓ, 2018). En territorios más alejados como es el caso de la Inglaterra romana, se documentan ocupaciones en cueva desde el siglo I d.C. hasta finales del siglo V d.C. y, si bien algunas tuvieron ocupación prehistórica, esta es poco significativa en su continuidad romana y aún menos en lo que respecta al período post-romano (BRANIGAN y DEARNE, 1992: 35-42). Del análisis de estas cavidades se deduce que su uso más común fue el de lugares de refugio ocasional, pero no necesariamente a consecuencia de una mayor inestabilidad social y política, sino más bien ligada a visitas «irregulares», como pudo ser el resguardo ante las inclemencias meteorológicas, lugares de descanso ocasional para pastores (quizás de manera estacional) e, incluso, como refugio ocasional de viajeros en los casos en los que se encuentran en las proximidades de una vía de comunicación. ${ }^{10}$ En definitiva, un conjunto de usos «irregulares» que dejarían un escaso bagaje de evidencias arqueológicas, constituidas fundamentalmente, como señalan Branigan y Dearne, por herramientas simples, pequeñas cantidades de cerámica y algunas evidencias de fuegos y usos alimentarios..$^{11}$ Finalmente, estos autores señalan que un cierto porcentaje de cuevas pudieron utilizarse para actividades artesanales y, en mucha menor medida, para usos rituales y/o funerarios. Todo ello, obviamente, sin perjuicio de que una misma cavidad pudiera cumplir con funciones distintas en diferentes momentos.

En el caso hispano, contamos con datos para las ocupaciones altoimperiales de cuevas en áreas concretas del sury del sureste peninsular. Por un lado, tenemos las cuevas de la zona de la Subbética cordobesa, con al menos dieciocho cavidades que presentan evidencias de época romana. Algunas de ellas presentan ocupaciones altoimperiales, pero la mayoría tienen una cronología de los siglos IV-V d.C., usándose únicamente unas pocas a lo largo de todo el período romano. En cualquier caso, se trata de restos de escasa entidad, lo que conlleva a considerar estas ocupaciones como presencias ocasionales y no de tipo doméstico, siendo además discontinuas en el tiempo, aunque a lo largo de varios siglos (VERA RODRÍGUEZ, 1991: 62-68; RUBIO VALVERDE, 2014: 217-218).

Una de esas ocupaciones que presentan una peculiaridad extendida a otras cavidades

9. Sin duda en esta interpretación pesó la visión primitivista y refractaria a la romanización de las poblaciones del norte peninsular que durante muchos años ha marcado la historiografía hispana partiendo de la obra de A. Schulten y A. Barbero y M. Vigil.

10. La relación entre cuevas con ocupación tardorromana (con numerosa moneda del siglo IV d.C.) y vías de comunicación se ha propuesto también para algunas cavidades del área entre el Ebro y el Garona, donde las ocupaciones puntuales de las mismas podrían estar vinculadas a la vigilancia de las vías y a la organización del territorio (RÉCHIN y DUMONTIER, 2013; TOBALINA et al, 2016).

11. Una de las menos evidentes de estas ocupaciones irregulares sería la de refugio de bandidos, de difícil documentación, pero que podría detectarse por el hallazgo de monedas y artículos metálicos, generalmente dispersados rápidamente, y, en cualquier caso, siempre de pequeño tamaño y bien escondidas, tal y como se ha propuesto para algunas cuevas inglesas e italianas (BRANIGAN y DEARNE, 1992: 17; CHRISTIE, 2006: 479). 
del sureste español es la de ser utilizadas como cuevas-santuarios desde el siglo II a.C. hasta el siglo II d.C., como en el caso de la cordobesa Cueva de la Murcielaguina (RUBIO VALVERDE, 2014: 219; MACHAUSE LÓPEZ, 2019).12 Sin embargo, la mayor parte de las cuevas de la zona Subbética y del sureste peninsular que presentan evidencias tempranas de ocupación romana, son interpretadas como lugares en relación con las actividades agropecuarias. Bien como lugares de almacenamiento de asentamientos rurales que se encuentran en sus proximidades, ${ }^{13}$ bien como lugares que por su ubicación en zonas más agrestes estarían relacionados con refugios ocasionales de pastores, como sería el caso de las cordobesas cuevas de Moñúa, del Ermitaño, Rodaero de Soto o la Sima del Francés, o de la zona pirenaica, como la cavidad M35 del Baix Pallars, así como diversas cavernas de la zona granadina y del noroeste murciano, donde también se documentan cuevas con ocupación puntual o estacional de época altoimperial vinculadas con la explotación forestal y las actividades ganaderas y/o cinegéticas (ADROHER et al, 2002: LÓPEZ-MONDÉJAR, 2009: 216-217; PÉREZ-ALMOGUERA et al, 2011; RUBIO VALVERDE, 2014: 219). Esta explicación del uso agropecuario de la mayor parte de las cavernas se extendería al período tardorromano, que es cuando se documenta la mayor utilización de las cuevas en áreas tan distantes como la subbética cordobesa o la zona pirenaica. En efecto, en la zona cordobesa el fenómeno arranca en el siglo III d.C., centrándose las ocupaciones entre finales del siglo IV y el siglo $\mathrm{V}$ d.C., pudiendo en algún caso documentarse ocupaciones del siglo VI y un indefinido uso en el período musulmán (CARMONA ÁVILA, 1990; VERA RODRÍGUEZ, 1991: 62-68; VERA RODRÍGUEZ, 1994: 69-71; RUBIO VALVERDE, 2014: 219-220). En la zona pirenaica encontramos también una concentración de utilizaciones en los siglos IV-V d.C., como en la cueva del Moro de Olvena, en el Pirineo Central, que se pone en relación con las actividades agropecuarias por su proximidad a vías de comunicación (AGUILERA ARAGÓN, 1996: 136; PÉREZ-ALMOGUERA et al, 2011: 107-116; RUBIO VALVERDE, 2014: 220), tal vez como consecuencia de la diversificación de espacios agropecuarios complementarios en función de sus posibilidades de uso, tal y como se evidencia para el siglo VI en la documentación del Monasterio de Asán (ARIÑO y DÍAZ, 2004: 223-238). Unos cambios en la economía que también lo serán en la propia sociedad que se está transformando y que ya en pleno período tardoantiguo evidenciará en muchos lugares la ruptura de los modelos romanos para dar lugar a nuevos modelos de explotación del campo dentro de unas nuevas lógicas campesinas, como se ha planteado para la explicación de muchas de las cavidades del País Vasco a partir de estos momentos, como los yacimientos de Los Husos (Álava) (QUIRÓS y ALONSO, 2007-2008: 1140).

Por otra parte, también en numerosos lugares de Italia -especialmente en Liguria- se pueden documentar reocupaciones de cuevas prehistóricas a lo largo del final del mundo romano y la Tardoantigüedad. Como señala N. Christie, no se trata necesariamente de ocupaciones marginales ni «pobres». ${ }^{14}$ Las noticias ofrecidas por Claudiano (De Bello Ghotico, 217224) sobre la ocupación de algunas cuevas por parte de gentes que disponían de abundantes recursos ante determinadas circunstancias, y la existencia en algunos sitios, como la Caverna de Arene Candide, de materiales arqueológicos que evidencian que la ocupación del siglo VI d.C. se vincula con los mercados urbanos hasta el siglo VII d.C., apuntan en esta dirección (CHRISTIE, 2006: 478-479).

12. Aunque este tipo de usos rituales, al igual que en otras zonas del sureste o en la Inglaterra romana, parece que ocupó un número muy reducido de cavidades (LÓPEZ-MONDÉJAR, 2009).

13. En Italia algunas cuevas ocupadas en estos períodos pudieron ser utilizadas como auténticas aldeas, o en relación con ellas, lo que ocurrirá incluso en cuevas con cronologías mucho más tardías (CHRISTIE, 2006: 478; MARTíN VISO, 2016: 44).

14. En este sentido, el citado autor señala que muchas cavidades, con sus condiciones estables, no presentan necesariamente unas condiciones de habitabilidad peores que las de las casas y poblados de la Tardoantigüedad, lo que podría suscribirse para las malas condiciones de las viviendas en la península ibérica (ARIÑO, 2013: 106-110). 
Igualmente se ha señalado para el caso italiano el uso de cavernas como lugares vinculados con los diversos episodios bélicos que asolaron Italia durante la Tardoantigüedad, puesto que, incluso en el presente, se utilizan como refugio en época de guerra. ${ }^{15}$

Otro de los usos que habitualmente se han esgrimido para explicar estas ocupaciones en cueva durante los períodos de la Tardoantigüedad son los usos religiosos y rituales para yacimientos concretos, bien paganos bien cristianos, tanto en el caso italiano como en el hispano y en otras áreas geográficas. Desde el punto de vista de las prácticas paganas, podríamos destacar yacimientos como la pequeña cueva de Arlampe (Bizkaia), con un yacimiento paleolítico en el que se han encontrado dos fosas excavadas en el suelo de la cavidad y en cuyo interior se han documentado fragmentos de TSHT, cerámica común romana, vidrios, objetos metálicos, restos de fauna, etc., todo ello con una cronología de los siglos IV-V d.C., y que se han interpretado como «fosas de ofrendas» relacionadas con algún tipo de ritual mágico-religioso en relación con una deidad ctónica (GUTIÉRREZ CUENCA et al, 2012). Y en Asturias, se ha interpretado la cueva de El Ferrán como un posible santuario en los siglos II-III d.C. (FANJUL PERAZA et al, 2010). También algunas cuevas en la zona entre el Ebro y el Garona podrían haberse usado como lugares privilegiados para seguir practicando rituales paganos en los siglos IV-V d.C. (TOBALINA et al, 2016: 203).

Más frecuentes son las explicaciones de estas evidencias en cuevas como parte de ritos funerarios. Así, en Asturias contamos con las cuevas de Entrellusa (Carreño), Chapipi (Grado), Valdediós (Villaviciosa), Alesga (Teverga) y Cueva Pequeña (Cabrales), que presentan evidencias de enterramientos entre los siglos IV y VIII d.C. y que, actualmente, se vinculan con enterramientos de prestigio (GUTIÉRREZ GONZÁLEZ, 2010: 69-77; REQUEJO PAGÉS, 2018: 86-87) y que, en algunos casos y debido a la aparición de jarritos litúrgicos -como en la propia cueva de Covadonga y otras cuevas cantábricas-, dio paso a su interpretación en el pasado como centros eremíticos vinculados a la primera cristianización de la región o que hubieran sido traídos por los refugiados visigodos tras la invasión musulmana (DIEGO SANTOS, 1979: 37 y 42; FERNÁNDEZ CONDE, 1993-1994). Un jarro de bronce visigodo encontrado en la antigua mina de cobre de El Milagro (Onís) también se ha reinterpretado como un escondrijo ritual en la mina, ya desde un ambiente cristiano (GUTIÉRREZ GONZÁLEZ, 2010: 71). Ya en el territorio leonés también se ha postulado la utilización de algunas cuevas en el área de la cordillera Cantábrica que presentan ocupaciones tardías, como posibles eremitorios o lugares con alguna vinculación religiosa, entre otras funciones, -como la Cueva de San Mateo (Pola de Gordón), la Cueva de San Pelayo (La Valcueva) o la Cueva de San Guillermo de Peñacorada (Cistierna)-, si bien con poca base documental para poder confirmar esta aseveración (GUTIÉRREZ GONZÁLEZ, 1982: 30-32; JIMENO GUERRA, 2018: 57-59 y 61-65).

La existencia de eremitorios vinculados a ese primer cristianismo, variable cronológicamente en función de cada área geográfica, se ha postulado también para algunas cuevas cordobesas que presentan materiales de importación en época tardía que no parecen propios de grupos pastoriles y que estarían en conexión con el asentamiento de una posible comunidad de monjes eremitas en los abrigos rocosos de El Arrimadizo. Lugar en el que también se documentó una necrópolis datable en el siglo VII d.C., contando una de sus losas con un grafito que presenta el inicio de un salmo bíblico (CARMONA ÁVILA, 1990;

15. Son ilustrativas al respecto las diferentes noticias ofrecidas por Amiano Marcelino (Rerum gestarum 17. 1. 8; 17. 12. 5) del uso de cuevas como lugares desde los que ocultarse y atacar por sorpresa a las tropas romanas por parte de germanos durante las campañas de Juliano. En las mismas condiciones su uso como escondite de armas y recursos es otra posibilidad, bien ejemplificada en época contemporánea en la leonesa cueva de La Cudrera de Colle, cercana a Boñar, en donde se ocultó dinamita durante la revolución de 1934 (JIMENO GUERRA, 2018: 67), en las recientes campañas de Afganistán o por parte del ISIS en Irak (El País, 30 de marzo de 2020) (https://elpais.com/internacional/2020-03-29/el-isis-encuentra-su-tora-bora.html?prm=ep-app 30/3/20 1033). 
RUBIO VALVERDE, 2014: 221-223). Un uso de cavidades por parte de comunidades monásticas próximas que también se postula para la cántabra de Astillo (HIERRO GÁRATE y MARTíNEZ VELASCO, 2016), así como para algunas italianas (CHRISTIE, 2006: 481). Por su parte, en la zona vasca, cuevas como Las Gabas, Los Moros, Goras y Pinedo, entre otras, asociadas a templos o iglesias de carácter rupestre, podrían haber funcionado en realidad como centros de culto relacionados con comunidades campesinas próximas e, incluso, con la existencia de aldeas rupestres como las que se documentan en otras zonas de Europa -bien documentadas en Italia- como lugares de habitación estables de larga y media duración, nunca marginales o aisladas (como señalan los hallazgos de DSP y TSHT que evidencian el acceso a redes de intercambios), y cuyo mejor ejemplo podríamos encontrarlo en las dos cuevas de Los Husos (QUIRÓS y ALONSO, 20072008: 1138-1139).

Sin embargo, es la zona cántabra, muy cercana a la Cueva de Guantes, la que arroja el más nutrido y peculiar grupo de cuevas con evidencias funerarias del período tardoantiguo en España. ${ }^{16}$ Cuevas que presentan restos de ocupación entre los siglos V y X (HIERRO GÁRATE, 2011; GUTIÉRREZ CUENCA y HIERRO GÁRATE, 2007; 2010-2012; 2012; 2016; 2016C; GUTIÉRREZ CUENCA et al, 2017). Nuevos hallazgos y el estudio en profundidad con nuevos métodos y perspectivas de los ya conocidos, han permitido en los últimos años reinterpretar estas cuevas que, tradicionalmente, se habían interpretado como ocupaciones relacionadas con la huida desde el sur de población visigoda tras la invasión musulmana. De esta manera hoy se entienden como el reflejo de la inclusión del área cántabra dentro del mundo visigodo y su ambiente cultural. ${ }^{17}$

Se trata de un significativo número de cavidades, como La Garma, Las Penas, Riocueva o Cudón, en las que se han podido documentar diversos objetos de época visigoda, muy variados, junto con restos de fauna, fragmentos de carbón, restos carbonizados de cereales (especialmente panizo y mijo, pero también cebada, trigo y escanda, así como lino) y, en algunos casos, restos humanos de individuos menores de 35 años, en una distribución por edades no coincidente con lo que se suele apreciar en las necrópolis al uso en la misma época (HIERRO GÁRATE, 2011; GUTIÉRREZ CUENCA y HIERRO GÁRATE, 2007; 2016 Y 2016B; GUTIÉRREZ CUENCA et al, 2017; ARIAS et al, 2018). Estos enterramientos, al menos en algunos casos como Riocueva, documentan cremaciones en el interior de la cueva, tratándose de sepulturas «vestidas» que se acompañan de diversos objetos de adorno personal y ajuares, especialmente herramientas para el trabajo textil y de otros usos, diversos recipientes metálicos, de madera y de vidrio (GUTIÉRREZ CUENCA y HIERRO GÁRATE, 2016: 165 Y 178-179). Igualmente, se suelen acompañar de recipientes cerámicos, muy frecuentemente pequeñas ollas globulares de cocina, con fondo plano, a torneta, de cocción irregular; algunos ejemplares poseen un asa de cinta y pico vertedor, con decoraciones de incisión y motivos de líneas horizontales y ondas (GUTIÉRREZ CUENCA y HIERRO GÁRATE, 2016C; GUTIÉRREZ CUENCA et al, 2017).

Este conjunto de objetos que acompañan una particular forma del tratamiento funerario colectivo (cráneos aplastados, huesos

16. A las que habría que añadir otros ejemplos de Palencia (Cueva Larga), Álava (Los Goros), La Rioja (Cueva del Tejón), Huesca (Cueva Foradada), Cuenca (minas de La Condenada y de Los Morceguillos, Cueva de los Riscos de la Escaleruela), Valencia (Cova del'Assut de Bellús), pero también de la Septimania y, con una cronología algo más temprana, en distintas zonas de Portugal (GUTIÉRREZ CUENCA y HIERRO GÁRATE, 2016: 171-175), así como, muy probablemente, la leonesa Cueva de la Cudrera de Colle (Boñar) (JIMENO GUERRA, 2018: 65-68).

17. En este sentido, se ha destacado que la mayor parte de estos testimonios funerarios remite a un marco cronológico coincidente con el período de fabricación y uso de guarniciones de cinturón del Tipo V de Ripoll, entre la segunda mitad del siglo VII y la primera del VIII d.C., pudiéndose prolongar hasta el final de centuria (HIERRO GÁRATE, 2011: 357 Y 389; GUTIÉRREZ CUENCA y HIERRO GÁRATE, 2012: 184-188). Si bien, desde el punto de vista de la cultura material, «las últimas décadas del Reino de Toledo y las primeras del de Asturias son completamente indistinguibles» (HIERRO GÁRATE, 2011: 357), pudiendo alargarse estos usos hasta esos primeros momentos del nuevo reino. 
cremados tras la descarnación, cremación de telas con cereales y fauna, etc.), en cuevas apartadas y, dentro de las mismas, en lugares de difícil acceso, muy hacia el interior de las cavidades, incluso sellándose con muros el acceso en algunos casos (Las Penas y Cueva Foradada) (HIERRO GÁRATE, 2011; GUTIÉRREZ CUENCA y HIERRO GÁRATE, 2016: 176-177), se aparta por completo de los enterramientos coetáneos, tanto de Hispania en general como de la propia área cántabra en particular (GUTIÉRREZ CUENCA, 2019). Por ello, se interpretan como el fruto de una situación excepcional y puntual: un episodio epidémico. Situación que provocaría una reacción de miedo, tanto al contagio como al posible retorno de los fallecidos en circunstancias poco habituales (HIERRO GÁRATE, 2011: 385-395; GUTIÉRREZ CUENCA y HIERRO GÁRATE, 2010-2012: 277).

Finalmente, en fechas recientes, se ha propuesto como explicación alternativa de las más tardías ocupaciones de estas cuevas (aquellas que se datarían en el siglo VIII, como ocurre con una buena parte de las cántabras), incluirlas en el contexto de la conquista islámica, relacionándose con grupos -especialmente de jóvenes, de ahí el sesgo demográfico que presentan los enterramientos- que escaparon hacia las montañas huyendo del cautiverio que les esperaba de cara al mercado de esclavos (ORTEGA, 2018: 100).

Pero, en conclusión, si observamos el conjunto de explicaciones sobre las ocupaciones de uso frecuente, pero ocasional, en cueva a lo largo de la tardoantigüedad, tanto en la península ibérica como en otras zonas de Europa, priman aquellas que interpretan este fenómeno como espacios de almacenaje, depósitos de carácter agropecuario, en definitiva. Muy posiblemente como refugios de pastores, incluso como puntos regulares de parada durante la trashumancia, o en las zonas de pasto local de los rebaños de una comunidad (BRANIGAN y DEARNE, 1992: 12; CHRISTIE, 2006: 479; BERGSVIK, 2018: 42;
VINGO, 2018: 180-181; WOJENJA, 2018: 242). ${ }^{18}$ En este sentido, por ejemplo, resulta esclarecedor que una buena parte de las cuevas que presentan algún tipo de utilización tardía en la montaña cantábrica leonesa evidencian su cercanía a cursos de agua, lo que parece un factor esencial de selección de las ubicaciones como consecuencia de las necesidades de abastecimiento de las labores agrícolas y ganaderas, como se puede ver en el valle de La Valcueva, de la Cueva de los Murciélagos en Mirantes de Luna y los Covachos de Canseco (JIMENO GUERRA, 2018: 68). Condiciones favorables por su cercanía a cursos de agua y proximidad a zonas aptas para el cultivo y el aprovechamiento de recursos pecuarios que también encontramos en los abrigos alaveses de Los Husos (QUIRÓS y ALONSO, 2007-2008). Un tipo de ocupaciones que se han definido recientemente para el área cantábrica en general como «cuevas-braña» (FANJUL PERAZA, 2011: 97). Y, en segundo lugar, tampoco se puede desdeñar el uso de estas como lugares de refugio ante la inseguridad de episodios muy concretos (CHRISTIE, 2006: 482; MÍNGUEZ y LOPES, 2012: 409). Explicaciones complementarias que se llegan a unir en ciertos momentos de la tardoantigüedad en zonas, como las cantábricas, donde la ganadería siempre debió desempeñar un papel destacado, papel reforzado ante la revitalización, documentada en muchas áreas geográficas, del pastoreo a partir del Bajo Imperio (ESTEBAN DELGADO, 1990: 345-346; QUIRÓS y ALONSO, 2007-2008: 1137; LECANDA, 2015: 1138-1139).

\section{3.- COMUNICACIONES Y PAISAJE TARDOANTIGUO EN LA CUEVA DE GUANTES}

El estudio del paisaje permite analizar un espacio bajo la perspectiva macro territorial penetrando en el área foco de interés, en este caso la cueva de Guantes, facilitando así la comprensión al análisis de ocupación territorial que justificaría el acceso en

18. Unas prácticas trashumantes que parecen ya muy presentes en la época romana en diversos puntos del Imperio y, más concretamente, en la zona de los Pirineos (COLOMINAS, 2020). 


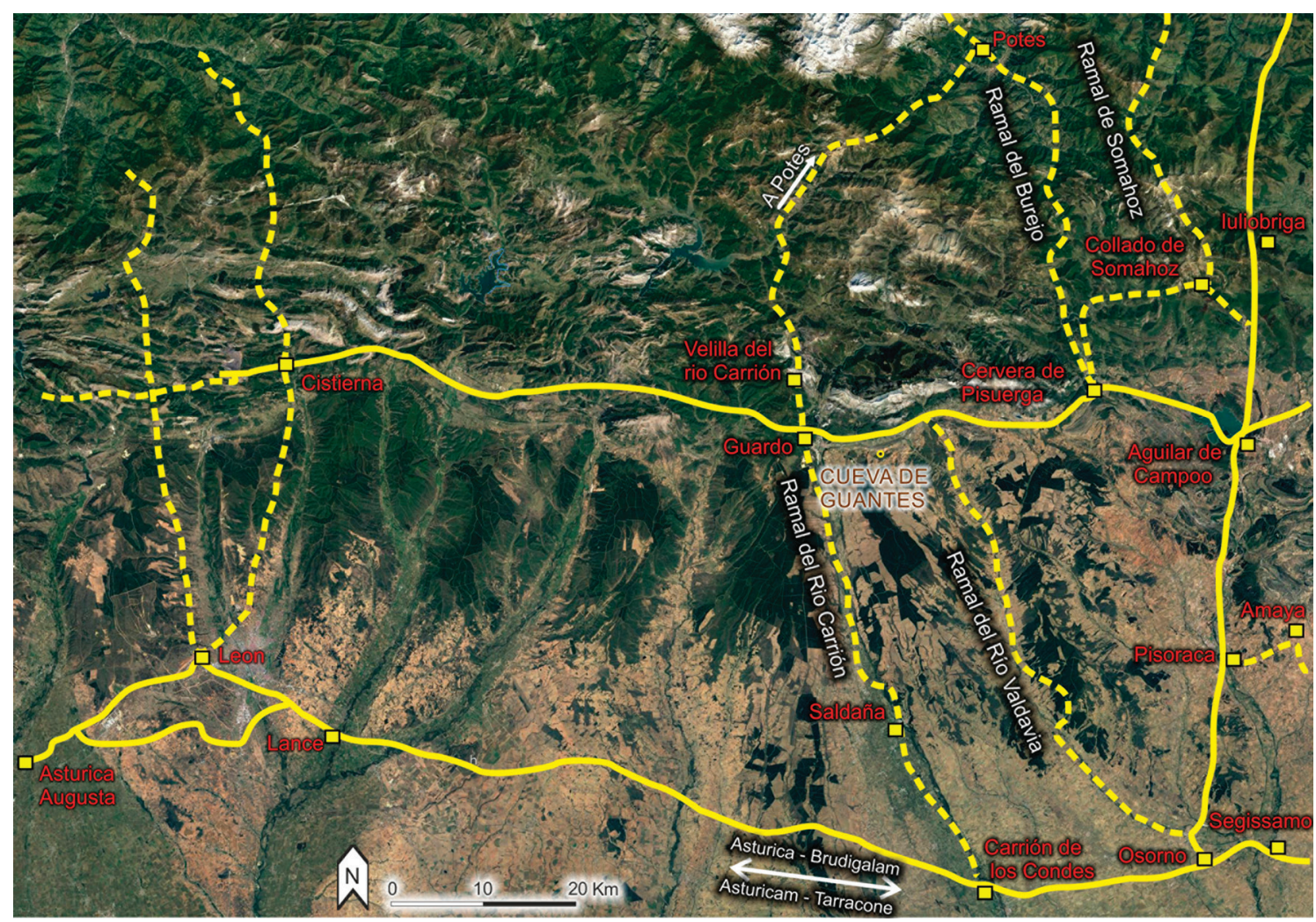

Fig. 2. Entramado viario en las cercanías de la Cueva de Guantes.

tiempos visigodos a la cueva. Como es sabido, la organización territorial tardoantigua vendrá marcada por la propia vertebración viaria diseñada desde tiempos romanos, pues la infraestructura de sus comunicaciones será reutilizada y acondicionada en las centurias visigodas (Fig. 2).

Debemos tener presente que, para el territorio fronterizo a la Cordillera Cantábrica, dada la orografía, nos enfrentamos a un estudio donde la articulación territorial, en la mayoría de los pasos, no sobrepasaría un tipo de construcción de simple tierra apisonada a modo de senda, aprovechando en gran medida corredores naturales de tránsito y marcas fluviales (MUÑIZ CASTRO, 1999: 291).

La propia posición de la Cueva de Guantes en la montaña palentina correspondiente al municipio de Santibañez de la Peña, resulta interesante al dibujarse en los límites fronterizos de lo que habría sido la primitiva Cantabria romana. Hemos de tener en mente que la jurisdicción territorial de territorio cántabro, en su demarcación meridional, parece que quedó delimitada desde el territorio de Cistierna a la orilla este del Esla hacia Pisoraca, Villadiego y montes de Oca. Por tanto, geográficamente el marco de estudio para el mundo antiguo correspondería con el denominado territorio cántabro-vacceo (IGLESIAS GIL y MUÑIZ CASTRO, 1992: 23), y que durante el periodo visigodo apenas sufre modificaciones (ÁLVAREZ LLOPIS y PEÑA BOCOS, 2005:16,23).

Para comprender el proceso de visigotización del territorio debemos partir del estudio de la administración territorial durante el periodo de romanización. La Cantabria romana habría quedado fraccionada en dos sectores, el norte montañoso con relieve accidentado y desniveles entre 1.000 y 2.500 metros (nuestra zona de estudio) y el sector sur con una orografía más dócil. El territorio de la Cantabria costera no fue apto para actividades agrícolas por lo que las vías, que en un primer momento fueron de uso militar, pasaron a cubrir una intencionalidad de favorecer los accesos a la Meseta, proporcionando así 
intercambios comerciales (GARCÍA GONZÁLEZ y FERNÁNDEZ DE MATA, 1998: 339).

En el sector meseteño debemos remarcar dos ejes principales de oriente a occidente según recoge el Itinerario de Antonino. Por un lado, la vía de Italia in Hispanias que une la Legio VII Gemina hacia Tarraco (vía 1 y 32) ${ }^{19}$ y por otro, de Hispania in Aequitania Asturica Augusta con el portus de Burdigala (vía 34) (SOLANA SAINZ, 1973: 15-16; MAÑANES PÉREZ y SOLANA SAINZ, 1985: 13-35 Y 136-139; HERNÁNDEZ GUERRA y SAGREDO SAN EUSTAQUIO, 1998: 143-145).

Por su parte, el Anónimo de Rávena, del siglo VII d.C., inspirado en el mapa romano, cita dos itinerarios que conectan el sector de estudio entre Herrera del Pisuerga, Palencia, a Carrión de los Condes (MAÑANES PÉREZ y SOLANA SAINZ, 1985: 100-111; HERNÁNDEZ GUERRA y SAGREDO SAN EUSTAQUIO, 1998: 146-47; ROLDÁN HERVÁS, 1975: 100).

Más en detalle, el principal eje comunicador entre los dos lados de la cordillera fue la vía Pisoraca-Iuliobriga hacia la costa (SOLANA SAINZ, 1981: 230-232), ${ }^{20}$ asociada a los pasos recogidos en la vía Legione VII Gemina ad Portum Blendium de las Tablas de Barro (FERNÁNDEZ OCHOA et al, 2012: 154).

En las Guerras Cántabras tuvo gran importancia la participación de la Legio IV Macedónica, que asentó su campamento en la actual Herrera de Pisuerga (Pisoraca). Desde allí, partía la vía romana de Somahoz-Salcedillo, que atravesaba el término de Aguilar de Campoo, quedando de ella el recuerdo de varios miliarios como son el de puente Nestar y el de Menaza y Aguilar (IGLESIAS GIL y MUÑIZ CASTRO, 1992: 110-112; HERNÁNDEZ GUERRA, 1994: $n^{\circ}$. 115; HERNÁNDEZ GUERRA y SAGREDO SAN EUSTAQUIO, 1998: 94). La Legio IV fue trasladada por Calígula, lo que da a entender un periodo de pacificación y florecimiento de asentamientos hispano-romanos por la zona, quedando Herrera de Pisuerga como centro organizador de las comunicaciones y, por tanto, del territorio (ALCALDE CRESPO, 1995: 107-108). ${ }^{21}$ En dirección sur, desde Herrera de Pisuerga la vía llegaba por el oeste de Osorno, donde se cruzaba con el acceso a Asturica Augusta, dirigiéndose hacia Carrión de los Condes por el paso del puente Villarna en Villadiezma. Dejaba al borde el despoblado de San Martín de Prevedo y el Monasterio de Santa Cruz, ambos enclaves citados en las fuentes medievales al paso del camino, ${ }^{22}$ además de un conjunto de necrópolis fechables desde los siglos IV-VI, y de los hallazgos de diversos materiales datables entre los siglos V-VI y otras estructuras edilicias de los siglos V-XI (FERNÁNDEZ GONZÁLEZ, 2018: 226-229).

Nuestro sector de estudio estaría contextualizado en el bellum cantambricun et asturum al que se refiere Floro $(11,33,46)$ y más concretamente en los acontecimientos del eje Amaya-Cervera de Pisuerga-Guardo del año 26 a.C. (HERNÁNDEZ GUERRA y SAGREDO SAN EUSTAQUIO, 1998: 26-27). ${ }^{23}$

Ni los miliarios documentados en Palencia ni las vías citadas en el Itinerario de Antonino sirven para estudiar los pasos por el territorio de Guardo (punto de referencia de la cueva de estudio) (HERNÁNDEZ GUERRA y SAGREDO Y SAN EUSTAQUIO, 1998: 143). Por tanto, podemos calificar como «secundarios» los accesos que a continuación analizamos y que serían pasos con marcado trazado sur-norte en dirección a la costa, jalonando los cauces de los ríos Carrión, Valdavia y Burejo (IGLESIAS GIL y MUÑIZ CASTRO, 1992: 87; BASTERRA ADÁN,

19. La vía 1 y 32 comparten recorrido hasta Virovesca

20. A. Shulten considera que esta vía militar dirección Portus Blendium fue el camino seguido por Augusto para penetrar en las montañas cántabras (SCHULTEN, 1943: 224-235).

21. Este eje también sirvió de comunicación a los dos campamentos romanos documentados en La Poza (CEPEDA OCAMPO, 2004: 391-402).

22. Como se puede ver en un documento de San Salvador de Oña fechado en 1017 o 1030 «... en cabo de la carrera viatreta III terras.... Et otras duas sobre carrera publica al portillo en termino de villa Preuvedo; a Sancta María extra via publicam...» (ÁLAMO, 1950: doc. 42; SOLANA SAINZ, 1974: 287, nota 142.)

23. Algunos investigadores proponen Cervera de Pisuerga como la antigua ciudad de Camarica (RUESGA HERREROS, 2007: 32). 
2009: 109). Existen dos ramales que desde Pisoraca toman dirección norte por el margen oeste de la vía principal. Uno de ellos es el ya citado del Collado de Somahoz, ${ }^{24}$ y el segundo, el más occidental, es la denominada vía del Burejo, que sigue el cauce de este río aguas arriba con dirección noroeste y que desde la propia Pisoraca comunicaba el valle de la Liébana por un paso en Piedrasluengas hasta Potes. ${ }^{25}$ De este modo también conectaba el Valle de Ojeda en dirección al núcleo de Cervera de Pisuerga, entroncando los cauces del Burejo y el Pisuerga. ${ }^{26}$ Es en este punto donde conectaba con el acceso al oeste, también de cronologías romanas, que permitiría llegar hasta la localidad de Guardo, desde el sur de Peña Horcada por Castrejón y Santibañez de la Peña, imitando el moderno trazado del ferrocarril Bilbao-La Robla en el tramo de Valdeolea-Guardo, y cuyo tránsito se mantendrá durante las centurias medievales (SOLANA SAINZ, 1973: 227; IGLESIAS GIL y MUÑIZ CASTRO, 1992: 138-140).

Desde Pisoraca, otro eje, más alejado de nuestra zona de estudio, era el paso principal sur-norte que se dirigía a Flaviobriga por Tritium correspondiente a citada la vía Asturica-Burgidalam y que, al paso de la mansio de Vindeleia, se bifurcaba al norte hacia Flaviobriga (GIL IGLESIAS GIL y MUÑIZ CASTRO, 1992: 145-162).

Lo interesante de este camino es que la vía realizaba un escorzo al sur ${ }^{27}$ antes de retomar la dirección norteña y es en este punto, en Segisamo, donde se documenta un ramal que partiría de Segisamo (dirección oeste) a Asturica Augusta, en una cota más sur, y paralelo al anteriormente citado acceso de Herrera de Pisuerga hacia Guardo (HERNÁNDEZ GUERRA, SAGREDO SAN EUSTAQUIO, 1998: 150). Este camino sería el que tomaba rumbo a Asturica Augusta y al paso de Dessobriga (actual Osorno) había sido jalonado por los miliarios de Padilla de Abajo (ABÁSOLO ÁLVAREZ, 1973: 349-350; MAÑANES PÉREZ y SOLANA SAINZ, 1985: 136-138, núms. 1 y 2; MORENO GALLO, 2001:72) rumbo a Carrión de los Condes y Astorga, siendo una de las primeras vías del territorio meseteño en ser estudiada en 1920 por A. Blázquez (1920: 5-8) (HERNÁNDEZ GUERRA, SAGREDO SAN EUSTAQUIO, 1998: 144). ${ }^{28}$

Además del trazado oeste hacia Asturica Augusta, parece que en el entorno de Padilla de Abajo se bifurcaba otro eje al norte que tomaba dirección a Peña Amaya, en donde en la cueva homónima se ha documentado presencia visigoda (GUTIÉRREZ CUENCA y HIERRO GÁRATE, 2010-12: 269-274), escenario también de la campaña del rey Leovigildo en el año 574 (AJA SÁNCHEZ, 2008: 253; QUINTANA LÓPEZ, 2017) y que según J. M. Solana (1981: 230) continuaría al norte hacia Castro Urdiales, delimitado con los miliarios de Otañes (LOSTAL PROS, 1992: 45 y 60-61, núms. 40, 55, 56).

24. El ramal de Somahoz es citado en el año 824 en el Fuero de Brañosera «...per illam civitatem antiquam (Peña Cilda?) et per illum Pandum...» (MUÑOZ Y ROMERO, 1847: 16-18). Pudo existir un camino que permitiera unir Somahoz con Cervera de Pisuerga y de esta manera, conectar con el camino al oeste que se dirigía a Guardo y Cistierna (HERNÁNDEZ GUERRA y SAGREDO SAN EUSTAQUIO, 1998:150).

25. Tal y como informa un documento de Santo Toribio de Liébana del año 959: «... via qui discurrit a Pautes (Potes)», y otro datado en 1001, «... sobre via qui discurrit a Bannes...» (SÁNCHEZ BELDA, 1948: docs. 57 y 79). Una vez visitado el Monasterio de Santo Toribio de Liébana, ya en la Baja Edad Media, el peregrino también tenía la opción de dirigirse hacia León por el acceso de Riaño.

26. El camino se encuentra acompañado de diversos hallazgos de cronologías romanas como son cerámicas (común y sigillata) y ladrillos en Dehesa de Montejo o la villa romana de Villarbermudo (NUÑO, 1991: 248 y 253). El sector norte de la vía desde Cervera de Pisuerga es reacondicionado en centurias medievales, cuando su trazado pasa al margen izquierdo del río aprovechando la construcción del puente de Cervera de Pisuerga y el de San Salvador de Cantamuda del siglo XIII. Sobre la comunicación entre el eje Pisoraca-Iuliobriga hacia Cervera de Pisuerga y Guardo véase SOLANA SAINZ, 1981: 220-221. Así mismo, se confirma la pervivencia de tránsito hacia el 1077 en un documento de San Salvador de Oña: «... et de antiqua carreta et a los penales de super uerezal de sumo de nio de cueruo...»; y en otro del 1148: «....et per al fixo de illa antiqua carrera...» (ÁLAMO, 1951: docs. 146 y 203). Otras citas sobre este paso viario en documentación medieval de los años 940 y 1096 son «...et de parte occidentis strata que discurrit as Castellum...», y «... et carrera que discurrit ubique... in villa que vocitant Nova iuxta Moneca...» (ÁLVAREZ PALENZUELA, 1970: docs. 1 y 5 , citado, con más referencias, en SOLANA SAINZ, 1981: 227, nota 68).

27. El enlace de Pisoraca a Segissamo es citado en el Anónimo de Rávena y fue estudiado por A. SCHULTEN (1943: 224).

28. Vía de Italia in Hispanias, citando la mansio de Lacobriga como Carrión de los Condes (ROLDÁN HERVÁS, 1975: 38-45). En este tramo se han documentado los dos miliarios en Padilla de Abajo (Burgos), correspondiendo a la vía Italia in Hispanias de Milán hasta la Legio VII Gemina y Asturica Augusta pasando por la mansio de Lacobriga (Carrión de los Condes). 
Siguiendo el cauce del río Carrión se documenta, aún en uso en tiempos medievales, un paso hacia territorio de la Liébana por el Puerto de Pineda. Pudo existir una vía natural, reproduciendo la cañada que desde Carrión de los Condes 29 (punto en el que transversalmente cruzaba la vía a Asturica Agusta en el paso del puente de Villadiezma sobre el río Villarna) se dirigía al norte hacia Saldaña y Guardo (CORTÉS ÁLVAREZ DE MIRANDA y RÍOS SANTOS, 1979: 44-49). Sobre este eje se produciría el retroceso musulmán en el año 844, permitiendo así la repoblación cristiana en territorios como Cabuerniga, Liébana y al sur hasta Simancas (CADIÑANOS BARDECI, 2002: 171).

En Velilla del Río Carrión, al norte de Guardo, existía una bifurcación de uno de los ramales que se dirigía al este por un puente, hoy bajo las aguas del embalse de Compuerto, hasta otro puente, el de Teblo en el puerto de Pineda y al menos en uso hasta el s. XII. ${ }^{30}$ En este punto es donde confluía con la citada vía a Potes y el Cantábrico que tomaba origen en Pisoraca y Cervera de Pisuerga. La segunda opción, documentada en diversos diplomas medievales del siglo X pertenecientes al Monasterio de Sahagún, era continuar el margen izquierdo del río Esla hacia Riaño y posteriormente León. ${ }^{31}$

Otro camino que conectaba con Guardo es el descrito por J. M. Solana Sainz (1981: 223-224) quien propone un acceso paralelo, al este, al descrito por el río Carrión, y que en este caso sería guiado por el río Valdavia desde el norte de Osorno (proveniente de Clunia), hacia Villavega, Villaeles, Buenavista, La Puebla, Congosto de Valdivia y Respenda. ${ }^{32}$ En este punto, dando continuidad a la propuesta de J. M. Solana y dada la posición del accidente orográfico de La Loma, es posible que el camino continuara dirección norte hacia Las Heras de la Peña, donde en el margen este del vial se conserva el topónimo "Calzada», y desde aquí entroncaría con la ya citada vía que al oeste se dirigía a Guardo.

La Cueva de Guantes está entre las localidades de Villaoliva de la Peña y Villanueva de Arriba a 6 kilómetros al este de Guardo, en el margen sur del río Heras, en el área oeste del Cerro de Santa Cruz. Por ello, su comunicación resulta excelente al estar al pie de la vía que desde Cervera de Pisuerga conectaba dirección oeste con Cistierna hacia León, y a escasos metros del ramal que desde el sur proviene del Osorno por el cauce del Valdavia.

El núcleo de Guardo puede presentarse como uno de los importantes focos del norte palentino (junto a Carrión de los Condes y Herrera de Pisuerga). ${ }^{33}$ Los principales accesos a Guardo serían cuatro: al norte el recientemente citado vial a Velilla del Río Carrión, al este-oeste con el eje Cervera de Pisuerga (proveniente del Collado de Somahoz, vía de Pisoraca a luliobriga) en la ruta que proseguía a Cistierna al oeste, y dirección sur, con Carrión de los Condes y Osorno, con pasos que seguían el río Carrión y el río Valdivia respectivamente, comunicando en ambos casos con el eje Asturicam Birdigaliam.

La comunicación en tiempos romano-visigodos ya ha quedado documentada supra, pero, además, deberíamos contemplar la idea de la existencia de accesos prerromanos. Por un lado, la cueva documenta ocupación pleistocénica; además, en el cercano enclave de Santibáñez de la Peña se cataloga una ocupación castreña prerromana de la II Edad del

29. Para los tiempos bajo medievales se propone un paso del Camino de Santiago que uniría Carrión de los Condes con Herrera de Pisuerga (ARROYO, s.f: 10-12)

30. Según diplomas del monasterio de Lebazana: «... illam carreram de Tebro...»; «... sicuti descendit ad illam carreram de Tebrego ...» (HERNÁNDEZ GUERRA y SAGREDO SAN EUSTAQUIO, 1998: 151, nota 817).

31. En un documento del año 959: «Alexi... et per termino de Atila et per illa via qui discurrit a villa...» (MÍNGUEZ FERNÁNDEZ, 1976: doc. 153).

32. Pese a la detallada descripción del autor, éste no recoge registros arqueológicos o históricos que confirmen tránsito por este camino ni para el período romano ni para los medievales.

33. En un texto del año 1860 se recoge un informe sobre las vías romanas en uso que partían de Astorga. Se cita textualmente el paso por «las montañas de Guardo» de un viario romano (hacia Astorga) aún en activo (ÁLVAREZ SACHIS y CARDITO ROLLÁN, 2000: 404). 
Hierro, La Loma, rodeada de recintos campamentales romanos que se enmarcan en el contexto del Bellum cantabricum (PERALTA LABRADOR, 2003: 303; FERNÁNDEZ ACEBO et al, 2010: 603-604). Durante tiempos bajomedievales, el principal foco de población debió venir sustentado por el cercano enclave del monasterio benedictino de San Román de Entrepeñas, así como un castillo, quedando por tanto confirmada la transición poblacional de manera continuada en el área más cercana a la Cueva de Guantes. ${ }^{34}$

Es notoria la existencia de yacimientos asociados a los accesos y ejes viarios existentes y que favorecen la comunicación de la comarca, siendo el paso principal el enclave de Pisoracam en la comunicación norte-sur PisoracamIuliobriga (FERNÁNDEZ GONZÁLEZ, 2018: 238). Los accesos principales de esta área de estudio, Italia in Hispanias (vía 1 y 32) y, por otro, de Hispania in Aequitania Asturica Augusta (vía 34), se mantuvieron como arterias principales del territorio para la población civil y militar hasta la propia invasión árabe, siendo, por ejemplo, zona de paso del rey suevo Rechiario en el año 449 en dirección a Francia (AJA SÁNCHEZ, 2008: 205), o zona de paso de Wamba en sus campañas contra los vascones (MARTínEZ PIZARRO, 2005: 47-48). No obstante, los numerosos ramales que se dibujan desde los dos ejes transversales ya mencionados del Itinerario de Antonino hacia territorios marginales y montañosos (como es el caso del sector norte de Guardo) pone en manifiesto la continuidad en la ocupación poblacional.

En definitiva, nuestra área en estudio, la zona en torno a Guardo, evidencia desde los tiempos de la conquista romana un cierto protagonismo. En efecto, según D. Cassio (3, 22, 5) y Suetonio (Aug. 26), sería el propio Augusto el que dirigiría las operaciones en el eje Amaya-Cervera de Pisuerga-Guardo durante el 26 a.C., para continuarlas en el 25 a.C. el legatus de la Citerior C. Antistio (HERNÁNDEZ GUERRA y SAGREDO SAN EUSTAQUIO, 1998: 26). Desde entonces, se fue desarrollando un conjunto de comunicaciones secundarias que pasaban por aquí, enlazando con las importantes vías que transcurrían no muy lejos. Un área en la que los romanos pudieron llegar a realizar algún tipo de trabajo minero en la zona de Velilla de Guardo (GARCÍA y BELLIDO y FERNÁNDEZ DE AVILÉS, 1958; HERNÁNDEZ GUERRA y SAGREDO SAN EUSTAQUIO, 1998: 158), localidad en la que se suele localizar las Fontes Tamarici citadas por Plinio (N.H. 31, 23) (TOVAR, 1989: 365, C-401). Área en la que se conocen distintos restos de época romana, incluyendo tres epígrafes de carácter funerario, conjunto de evidencias que apuntan a un poblamiento en torno al siglo II d.C. (SOLANA, 1981: 39; HERNÁNDEZ GUERRA, 1994: núms. 89, 144 Y 147; HERNÁNDEZ GUERRA y SAGREDO SAN EUSTAQUIO, 1998: 97 y 109-110). Y, más hacia el sur del área de la Cueva de Guantes, en Vega de Riacos, también se ha podido documentar un yacimiento del que procede una estela funeraria doble dedicada a dos difuntos pertenecientes a la tribu de los orgenomescos, datable entre los siglos II-III d.C. (HERNÁNDEZ GUERRA, 1994: $n^{0} 87$ ).

Se ha constatado una cierta continuidad de poblamiento para el período tardoantiguo en el territorio cántabro-palentino (ALONSO ÁVILA, 1985: 283-284; FERNÁNDEZ GONZÁLEZ, 2018: 232). Las reocupaciones tipo villae, la llegada de aldeas, poblados fortificados en altura, la pervivencia de espacios para actividades agropecuarias y la creación de centros sacralizados, como cementerios, monasterios o iglesias, confirman también el aprovechamiento del entramado viario heredado de Roma, siendo mantenidas dichas calzadas en siglos sucesivos (GARCÍA DE CASTRO, 1995: 120-124; AJA SÁNCHEZ, 2008: 207-208; DÍEZ HERRERA, 2008: 273; BOHIGAS ROLDÁN y GUTIÉRREZ PÉREZ, 2012; CENTENO CEA ET

34. En el año 940 se menciona la existencia de una vía que circulaba al oeste del castillo, coincidiendo con el descrito camino de Cervera de Pisuerga hacia Guardo: «...de parte occidentis strata que discurrit ad castellum...» (DÍEZ MERINO, 2001:53-54; MEDIAVILLA DE GALA, 2011:79-96). 
AL, 2016; CRUZ SÁNCHEZ y MARTÍN RODRÍGUEZ, 2012; TEJERIZO, 2017: 361-382). ${ }^{35}$ Y con respecto a la ocupación de época visigoda en el área palentina, se ha podido evidenciar su intensidad en una buena parte de la misma, especialmente en la zona sur de la provincia y también en buena medida en relación con las vías de comunicación (PALOL, 1970: 30-44; ALONSO ÁVILA, 1985: 282-295; MOLINA, 1995; DEL AMO y PÉREZ RODRÍGUEZ, 2006: 122-125) (Fig. 3). La presencia de hallazgos visigodos es un buen aval para confirmar la necesidad de una transitabilidad del espacio tanto en períodos de paz como de conquista. Sabemos que estas vías, en especial la de Pisoraca ad Portum Blendium, la ruta del Ebro, la variante del Collado de Somahoz y la vía hacia Flaviobriga, siguieron en uso durante el bajo Imperio, tal y como atestiguan miliarios y una continuidad de diversos hábitats, más bien de carácter campesino, si bien con transformaciones que nos hablan del uso de estas rutas para dar salida a los excedentes de las explotaciones de la meseta hacia los puertos cantábricos (FERNÁNDEZ GONZÁLEZ, 2018: 235-236). Por otra parte, el proceso invasor que gesta la llegada del Reino visigodo se «beneficia» de los viarios romanos, pero simultáneamente se constata la destrucción de parte de ese viario para dificultar los avances enemigos (IGLESIAS GIL y MUÑIZ CASTRO, 1992: 26). Sin embargo, la permanencia e, incluso, mayor densidad poblacional en las zonas limítrofes entre Cantabria y la Meseta durante los siglos VI-VIII d.C. se puede vincular a esa permanencia en el uso de los viales y en relación con ellos y la salida desde la Meseta: con concentraciones de yacimientos en el noroeste de Palencia y norte de Burgos, y un poco más hacia el sur yacimientos como los del conjunto del Cañón de la Horadada, Monte Cildá, Aguilar de Campoo, Peña Amaya y Cuevas de Amaya (FERNÁNDEZ GONZÁLEZ, 2015: 64; FERNÁNDEZ GONZÁLEZ, 2018: 237238; SANTONJA GÓMEZ et al, 1982; LECANDA, 2015; QUINTANA LÓPEZ, 2017).

La red viaria, por tanto, en el caso cántabro y palentino, sirvió para facilitar la dominación visigoda - si bien ya antes lo había hecho en los diversos sucesos violentos que protagonizaron el momento final del Imperio romano y el inicio de la llegada de pueblos germanos-, habiéndose aprovechado Leovigildo de las vías meridionales como fuerza militar para las comunicaciones entre el norte y la capital toledana, pero también para posibles desplazamientos posteriores de los monarcas visigodos (ALONSO ÁVILA, 1985: 271-282; DÍAZ, 1994; OCEJO HERRERO et al, 2012: 276-283; VALVERDE CASTRO, 2017). De hecho, en el 494 el proceso de ocupación del territorio meseteño por parte de los visigodos es algo tan generalizado que la Crónica de Zaragoza señala "Gotthi in Hispanias ingressi sunt» (IX, II, 22), encontrándonos una importante concentración de asentamientos de este pueblo en la zona centro-oriental de la Meseta, hasta el punto de ser recordada la zona como "Campos Góticos», famosos por su trigo, en la Crónica Albeldense (3, VII), una zona que, precisamente por su riqueza agrícola, debió de ser escogida por una buena parte de los aristócratas godos para situar sus posesiones (PALOL, 1970: 28-32; DÍAZ, 1994: 466 y 471). ${ }^{36}$

Las comunicaciones están en constante evolución, caminos adaptados a las necesidades del momento y a la orografía sufren acondicionamientos, creación de nuevas bifurcaciones o abandonos. En el caso de estudio, hemos observado el uso de pasos naturales y el dibujo de trazados que imitan el diseño

35. Cánones conciliares y leyes visigodas recogen la normativa de hábitat reflejando términos tipo castellum, castrum, civitas... (SÁNCHEZ BELDA, 1948, doc. 13; REVUELTA CARBAJO, 1997). Se acentúa la política militar visigoda con las reformas de Chindasvinto y Recesvinto lo que requería la presencia de soldados en enclaves tipo «castillo». Ello implicaba necesariamente tareas de vigilancia, control y defensa, siendo necesario el paso por las calzadas (AJA SÁNCHEZ, 2008: 214; DÍEZ HERRERA, 2008: 266).

36. Estos «Campos Góticos» serán citados también en numerosas ocasiones por las fuentes medievales como por ejemplo en JIMENEZ DE RADA, Historia de rebus Hispanie 4, 5, 22, identificándose habitualmente con Tierra de Campos, abarcando el espacio recogido entre los ríos Esla al oeste, Carrión y Pisuerga al este y el Duero al sur, comprendiendo, por lo tanto, parte de las actuales provincias de León, Palencia, Valladolid y Zamora (MARTÍNEZ ORTEGA, 1998: 310-311). Es en esta zona, que se identifica con una intensa visigotización, en donde se ha postulado que se encontrarían los talleres de los característicos jarritos litúrgicos visigodos que se documentan a lo largo de la zona cantábrica (DIEGO SANTOS, 1979: 42). 
orográfico, confirmando la existencia de pasos incluso en periodos prerromanos, pero que también se seguirán usando durante los medievales, como podemos entrever en las menciones como las de la Crónica de Nájera (MARTÍN ORTEGA, 1998: 310-321).

En definitiva, el tremís de la Cueva de Guantes no desentona con la idea de que la moneda visigoda suele aparecer en los entornos de las antiguas vías romanas que unían las ciudades, confirmándose a su vez la evidencia sobre el uso en época visigoda de estas vías romanas, tanto terrestres como fluviales, así como el comercio exterior (PALOL, 1970: 29; MAROT, 2001: 149; RUIZ TRAPERO, 2004: 180 y 189). De este modo, por ejemplo, se pueden constatar en la antigua vía entre Mérida y Astorga, y en esa área de la Lusitania situada entre el Duero y el Tajo a través de diversas vías (MARTíN-ESQUIVEL y BLÁZQUEZ-CERRATO, 2018).37

\section{4.- LOS MATERIALES}

Este complejo kárstico había recibido una atención muy marginal desde los años ochenta del siglo XX, cuando fueron localizados en el seno de la carta arqueológica de la región. Durante los trabajos de esta, y en el proceso de excavación actual, se recogieron una serie de pequeños fragmentos cerámicos en superficie de muy difícil adscripción crono-cultural. La localización de estos lotes se corresponde con un nivel superficial de color negro o muy oscuro a consecuencia de su alto nivel de materia orgánica (nivel 101, 201 y 301A) presente en todos los sondeos de la Galería 1. Un nivel pobre en restos, pareciendo los encontrados corresponder a fauna sub-reciente, lo que, junto con los escasos hallazgos de cerámicas, pesas de telar y la moneda aquí estudiada, llevó a datar este nivel en el Holoceno (MATEOS CACHORRO

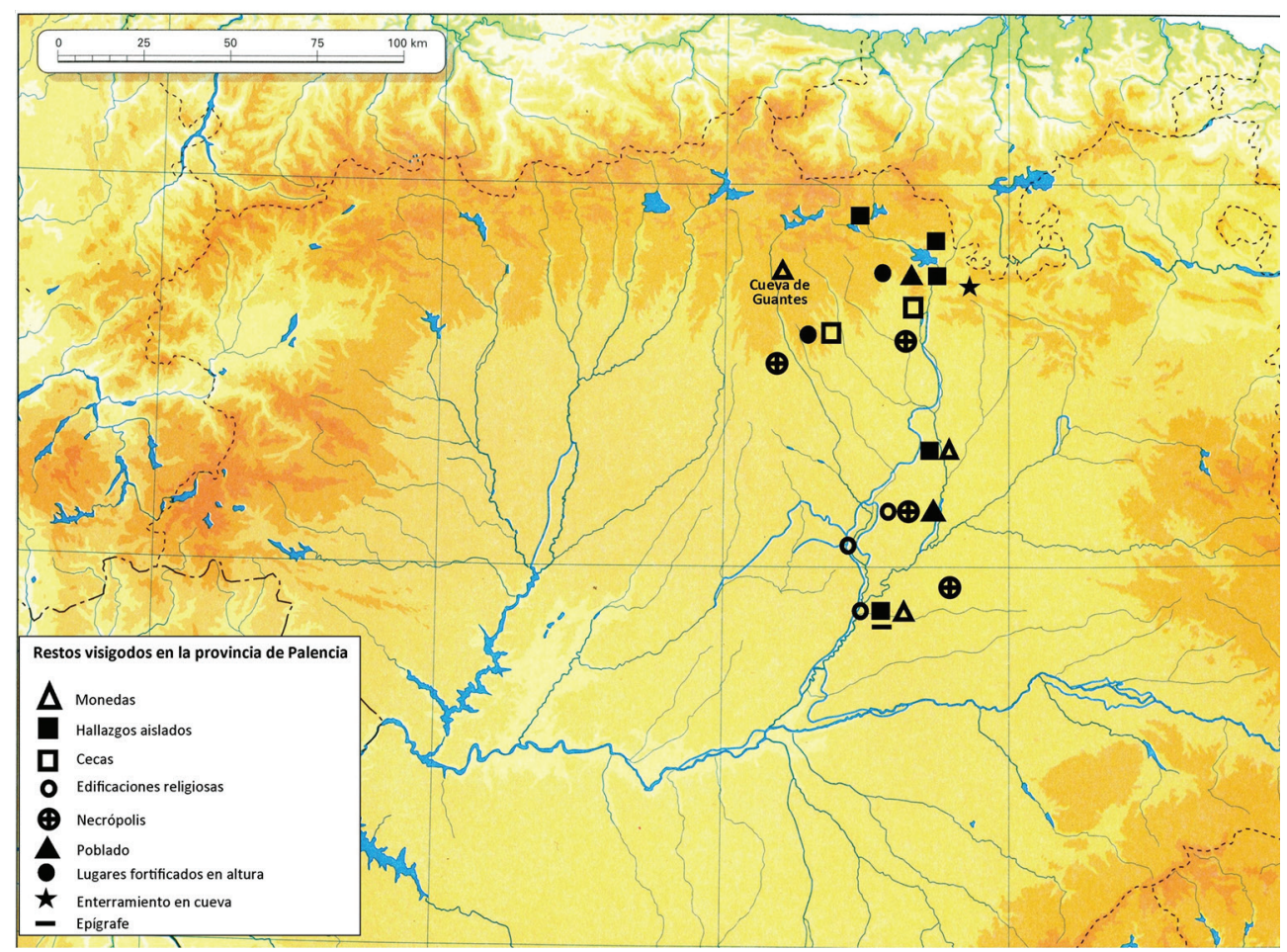

Fig. 3. Evidencias de poblamiento de época visigoda en la provincia de Palencia.

\footnotetext{
37. A este respecto aún continúa abierto un debate sobre si la moneda visigoda circuló intensamente, como una auténtica circulación comercial además de fiscal. A favor de esa circulación se encuentran autores como Barral (1976: 66-67 y 143-162), Metcalf (1986: 310-315) o Marot (2001: 150). En contra, Pliego (2009: I, 219-230; 2015: 37-41 y 2020), Retamero (2011: 193-196), Martín Viso (2008), Martín Esquivel (2018: 265) y, con serias dudas, Castro Priego (2016: 49-51). En general, sobre la tributación en la Hispania visigoda, véase VALVERDE CASTRO, 2007 (en relación con la monarquía) y MARTín VISO, 2013 (con respecto a las prácticas locales).
} 
Y RODRÍGUEZ MÉNDEZ, 2017b: 34 y 36). ${ }^{38}$ Se trata de cerámica a mano y a torno, y en la que los ambientes de cocción son tanto reductores como oxidantes. La sensación que ofrece el lote es de una posible mezcla de cronologías que irían desde la Edad del Hierro hasta el período Alto Medieval, si bien el predominio del lote parece adscribirse más bien a época protohistórica.

\subsection{Afiladera}

Con respecto a lo que inicialmente se interpretó como una posible «pesa de telar» (Fig. 4), se trata de un bloque de tendencia prismática, estrechándose en la parte superior y rematándose en círculo, con una perforación muy bien realizada y realzada. En la parte distal, que se encuentra rota, se pueden observar los restos de un biselado. Está elaborada en piedra, tal vez esquisto. A la espera de un estudio detallado de esta pieza se la ha venido clasificando como una pesa de telar. Se trata de artefactos que suelen realizarse en arcilla, con tamaños y formas muy diversas, así como con un número de perforaciones variables, y que se suelen identificar en la literatura arqueológica con la producción textil realizada en un telar donde la urdimbre era tensada con pesas, comunes tanto a época protohistóricas como a la romana (CASTRO CUREL, 1985; ALFARO GINER, 1997: 47-50). Durante el Calcolítico se ha postulado la existencia de telares de placas de piedra (CARDITO ROLLÁN, 1996), y se conocen algunos ejemplares en madera -aparecidos junto con otros objetos vinculados a la actividad textil- en contextos de la Edad del Hierro, como el de la relativamente cercana Cueva de El Aspio (Ruesga, Cantabria) (SMITH y MUÑOZ, 2010: 685, Fig. 7; LUIS MARIÑO, 2014: 138), así como en piedra en contextos castreños de la II Edad del Hierro del noroeste, como en la Corona de Corporales (cuarcita, arenisca, esquisto), donde aparecieron junto a una pesa de cerámica (SÁNCHEZ-PALENCIA y FERNÁNDEZ-POSSE, 1985: 271-272, Fig. 124 y Lám. XLII),
Llagú (cuarcita), del estilo de las «poutadas» gallegas, y que han sido interpretadas en relación con labores pesqueras, extremo discutido en este caso al considerarlas más bien en relación con labores textiles (BERROCAL-RANGEL et al, 2002: 207-208, Fig. 81, 1-3), o en Viladonga (ROMERO SUÁREZ, 2003: 263). Pero también se han podido documentar grandes pesas perforadas en piedra en yacimientos de época romana como Santa Marta de Lucenza (Orense) y de cronologías medievales, como Apordús (Navarra), los tres ejemplares en caliza de Peñaferruz (Gijón) o Cotam (Gran Bretaña) (ROMERO SUÁREZ, 2003: 262-265, Figs. 7, 8 y 9).

Sin embargo, el material usado en la inmensa mayoría de las ocasiones es la arcilla. Así ocurre con los ejemplares característicos del período romano (RUSTICO, 2013), bien documentados en el área palentina (DEL AMO y PÉREZ RODRÍGUEZ, 2006: 113-114), y de los que el de Guantes difiere mucho tipológicamente, además, aunque pueden existir variantes significativas a estas formas comunes durante la época romana (RAPOSO et al, 1989: 87). En la cueva cántabra de Linar, en cronología tardoantiguas-altomedievales, se documentó un conjunto de pesas de arcilla que podrían pertenecer a uno de estos telares verticales (GUTIÉRREZ CUENCA y HIERRO GÁRATE, 2012: 193).

Ahora bien, algunos autores han manifestado las dudas sobre la identificación de los pondus con pesas de telar, estableciendo una serie de criterios para esta identificación que pasan por el hallazgo de conjuntos compuestos por un número abundante de ejemplares similares en forma y peso, en niveles de suelo de habitación en contextos domésticos (CASTRO CUREL, 1985: 249).

Por otra parte, los instrumentos relacionados con la actividad textil de carácter doméstico y de subsistencia, posiblemente un trabajo femenino, son relativamente abundantes durante la Tardoantigüedad y la alta Edad

38. Estos materiales se encuentran en proceso de estudio, ofreciendo aquí una mera aproximación a los mismos con la intención de contextualizar el hallazgo del tremís objeto de estudio en esta publicación. 


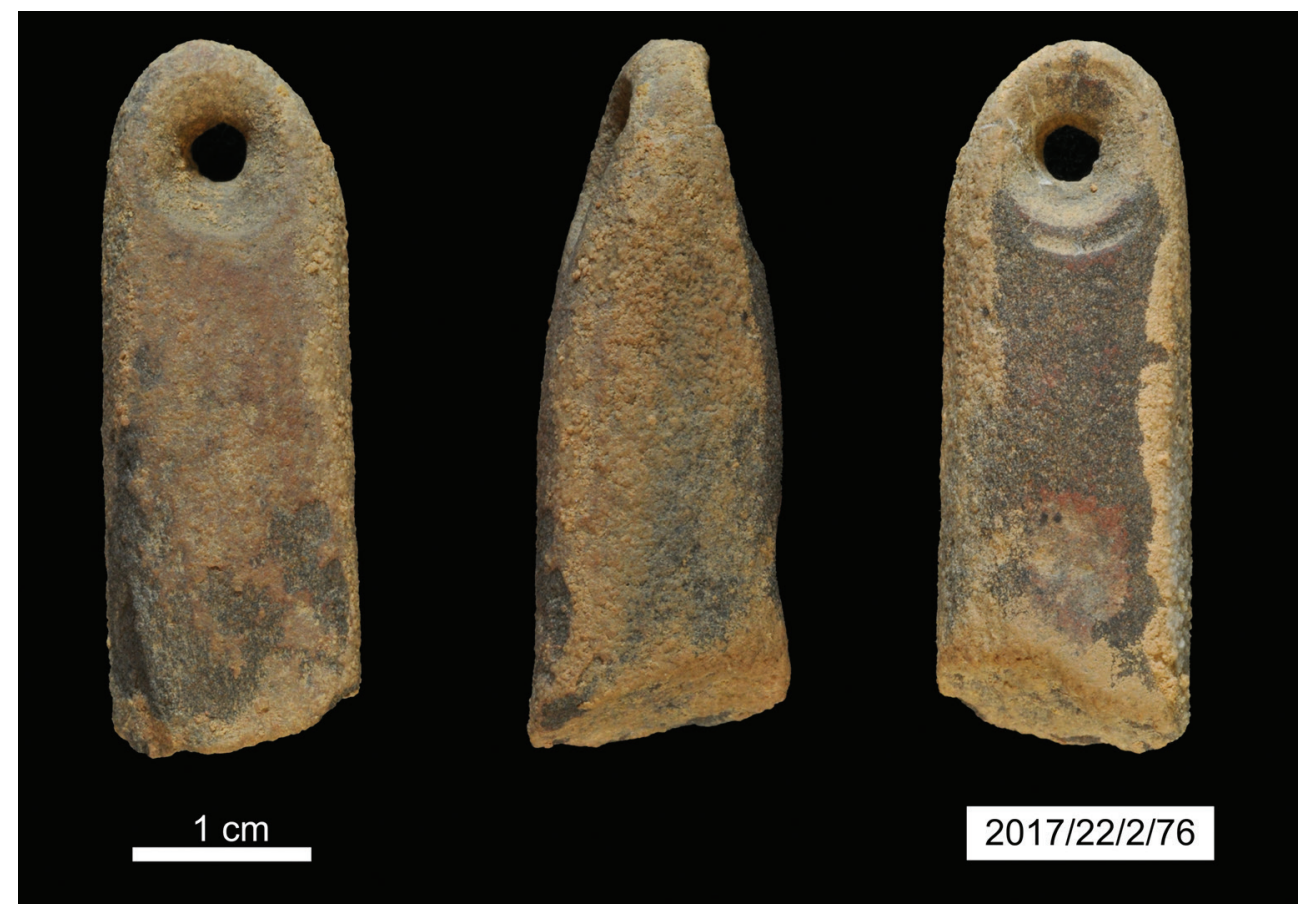

Fig. 4. Afiladera.

Media en el cercano territorio de Cantabria, especialmente en cuevas, datándose en su mayor parte entre los siglos VI y X d.C., al igual que ocurre en otras regiones europeas. ${ }^{39}$ Estos instrumentos se encuentran relacionados con el hilado (fusayolas, ganchos de hueso, ruecas de mano) y con el tejido (punzones y pesas de telar) (GUTIÉRREZ CUENCA y HIERRO GÁRATE, 2010; GUTIÉRREZ CUENCA y HIERRO GÁRATE, 2016b), llegando incluso a documentarse un fragmento de tela parcialmente carbonizada en la Cueva de Riocueva formando parte de un contexto sepulcral de época visigoda (GUTIÉRREZ CUENCA et al, 2014). Sin embargo, ninguno de estos objetos se documenta por el momento en Guantes, siendo además las pesas de telar de un tipo completamente diferente al nuestro. En cualquier caso, no podemos olvidar la importancia simbólica que los tejidos y diversos accesorios de indumentaria tuvieron durante la Antigüedad Tardía y la Alta Edad Media dentro de los contextos funerarios por todo el Mediterráneo (PINAR y TURELL, 2007), si bien en el caso de Guantes no parece que nos encontremos ante un entorno funerario.
Por todo lo anteriormente expuesto, consideramos que podemos encontrarnos ante un tipo de pieza lítica que podemos clasificar como «afiladera», relativamente frecuente en diversos tipos de contextos cronológicos, especialmente en los de la II Edad del Hierro, encontrándolas en yacimientos como Pintia (Valladolid), La Corona de Corporales (León), Meirás (La Coruña), en los asturianos de Larón, Campa Torres, Pendia, Arancedo, o en el navarro de La Custodia (SANZ MÍNGUEZ et al, 2011: 226; SÁNCHEZ-PALENCIA y FERNÁNDEZ-POSSE, 1985: 270, Fig. 124 y Lám. XLI; Maya González y Cuesta Toribio, 2001: 225 y 227, Fig. 151), pero también en cronologías tardorromanas y tardoantiguas, como en Gran Bretaña (Heybridge), en las necrópolis rurales de los siglos IV-V d.C., o en villas tardías como Quintanilla de la Cueza (Palencia), y ampliamente en contextos medievales, como en Veranes y Peñaferruz (Gijón) (FUENTES DOMÍNGUEZ, 1989: 158; MARTÍN GUTIÉRREZ, 2000: 209; ROMERO SUÁREZ, 2003: 258-260, Fig. 2). Su importancia económica llevó a que fueran explotadas de forma industrial durante

39. Se trata de las cuevas del Linar, de Cudón, del Calero II, de Las Penas, del Portillo del Arenal y del Juyo (GUTIÉRREZ CUENCA y HIERRO GÁRATE, 2010: 279, FIG. 18) 
el período romano (MOYA MALENO, 2008). Se trata de piezas que, dentro de su variabilidad, son siempre alargadas y aplastadas, de forma y sección rectangular o trapezoidal, en arenisca, caliza y cuarcita deleznable (usadas como afiladeras propiamente) o piedras más duras, como los cantos rodados de cuarcita dura o esquisto, para su uso como asentadores de filo (SÁNCHEZ-PALENCIA y FERNÁNDEZ-POSSE, 1985: 270). Su uso suele ligarse al afilado del instrumental agrícola. La aquí presentada tiene como peculiaridad presentar una perforación cilíndrica para su transporte, de forma similar a ejemplares documentados en Numancia (WATTENBERG, 1983: 111), Quintanilla de la Cueza (MARTíN GUTIÉRREZ, 2000: 206, Lám. 4) o, ya en cronologías medievales, en Peñaferruz (ROMERO SUÁREZ, 2003: 258259, Láms. 2 y 3).

\subsection{Peine}

Igualmente, en estos niveles se recogió un fragmento de placa triangular en hueso o asta de ciervo con decoración geométrica de dos círculos con punto central (FIG.5), presentando uno de ellos un orificio resaltado que traspasa por completo la placa, y el otro la marca del taladro que no llegó a realizar por completo la perforación con un taladro de arco o parahuso. Por el material y tipo de decoración y perforaciones (posiblemente para remaches metálicos) pudiera tratarse de un elemento perteneciente a un peine o estuche de peine en proceso de elaboración y que, debido tal vez a algún defecto, no llegó a terminarse reutilizándose para otra función. Podríamos encontrarnos ante un fragmento de la placa central (forzal) -tal vez triangular- de un peine compuesto (PICOD et al, 2016: 38).40
La decoración de circulitos con punto central es muy frecuente en la industria ósea desde la protohistoria hasta los tiempos romanos, siendo muy característica en el trabajo artesanal de la industria ósea en época tardorromana y medieval e, incluso, en contextos islámicos (MAYA GONZÁLEZ y CUESTA TORIBIO, 2001: 222; BERROCAL-RANGEL et al, 2002: 204-205; GUTIÉRREZ GONZÁLEZ e IBÁÑEZ CALZADA, 2003: 286). Es un tipo de decoración que se utilizó también en apliques, placas e incrustaciones en hueso o asta para arquetas, diversos tipos de muebles y utensilios de madera y de hierro. Apliques como los encontrados en Peñaferruz (Gijón), con una cronología en torno a la segunda mitad del siglo XII o inicios del siglo XIII (GUTIÉRREZ GONZÁLEZ e IBÁÑEZ CALZADA, 2003: 285, FIG. 13). Es una técnica que también se utilizó con cierta frecuencia en la elaboración de enmangues de cuchillos, como el que se conoce en la cercana cueva cántabra de Los Hornucos, en Suano (Hermandad de Campoo de Suso) (GUTIÉRREZ CUENCA y HIERRO GÁRATE, 2012: 195), ${ }^{41}$ o en las villas romanas tardías de los siglos IV-V d.C., como Quintanilla de la Cueza (MARTíN GUTIÉRREZ, 2000: 204, Lám. 2), o la de Liédena (MERQUÍRIZ, 2009: 190-191), pero que también se documentan, con un ejemplar muy similar, en la cueva polaca de Wierzchowska Górna, datada en cronologías de la Edad Media temprana (WOJENKA, 2018: 237, Fig. 14.4.8). ${ }^{42}$

Los peines (pecten) no son un hallazgo habitual en la península ibérica en la época romana, siendo especialmente escasos los conservados del período visigodo. En general, los peines de época romana son anchos y cortos. Pueden tener decoración calada, si bien son de tipo simple (MORONI, 2013: 232-233, Fig.

\footnotetext{
40. La utilización como placa ósea para la fabricación de botones tampoco es descartable, si bien responde a un formato distinto, como los documentados en el siglo XVIII (VITEZOVIC, 2016: 181-182).

41. Cueva posiblemente en vinculación con la variante por el collado de Somahoz (FERNÁNDEZ GONZÁLEZ, 2018: 232).

42. Los mangos de cuchillo en hueso con decoración de círculos son relativamente comunes en época romana (MORONI, 2013: 235, FIG. 6.6). Pero también en objetos muy variados de época tardorromana y bizantina, que van desde brazaletes hasta partes de monederos (VITEZOVIC, 2016: 58-61 y 230).
} 


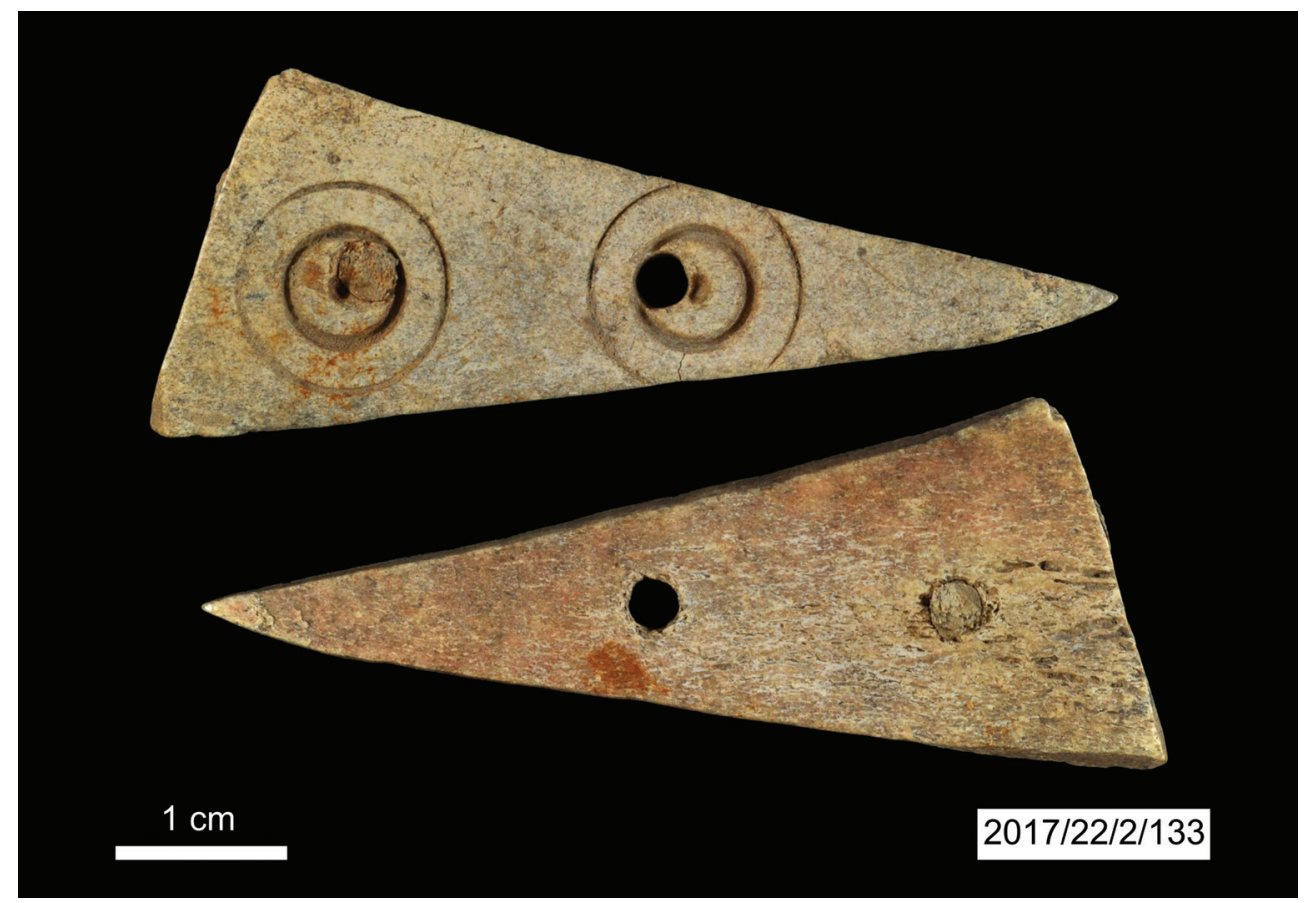

Fig. 5. Parte delantera del fragmento sin terminar de un posible peine en hueso o asta.

4.3), ${ }^{43}$ pudiendo realizarse en madera, como ocurre en contextos militares (DERKS y WOUTER, 2010). Los compuestos con estuche y realizados en asta de ciervo se suelen considerar el resultado de una evolución de los anteriores. Se trata de unos productos característicos del centro-norte de Europa durante el período de las migraciones, difundiéndose de esta manera por las provincias romanas. Los de tipo compuesto, con doble fila de púas y estuche articulado, especialmente poco frecuentes, son galo-romanos (siglos IV-V), lombardos y ostrogodos, de los siglos V-VI, encontrándose habitualmente en contextos funerarios (STOLL, 1939; PETITJEAN, 1995; ASHBY, 2006; RIJKELIJKHUIZEN, 2011; VITEZOVIC, 2016: 20, 229, 279 y 287; PICOD et al, 2016; HERRÁEZ MARTÍN, 2017: 248-249). Se conocen dos ejemplares, muy similares en la funda que poseen, de la catedral de Pamplona y de la Plaza del
Rey de Barcelona, datándose el primero en los siglos IV-V d.C. y el segundo entre el VI-VII d.C. (BELTRÁN DE HEREDIA, 2001: 36, Fig. 2; MERQUÍRIZ, 2009: 171), muy similar el pamplonés a un ejemplar de la catedral de Ginebra, y la decoración de su funda a la de las tumbas germanas de Württemberg (STOLL, 1939: FIG. 8.6). También de época visigoda - o cercana-, se conocen los ejemplares de Cacabelos, con cronologías de los siglos IV-V, y los de las necrópolis de Duratón (V-VII), Herrera de Pisuerga y de Castiltierra (PÉREZ-RODRÍGUEZ ARAGÓN, 1996; HERRÁEZ MARTíN, 2017: 248).

Los peines seguirán constituyendo elementos de prestigio durante la etapa inmediatamente posterior, tal y como podemos atestiguar en tumbas de carácter femenino de la época vikinga, si bien con tipos decorativos diferentes a los de época tardoantigua,

43. Un ejemplar muy bien conservado (inédito) puede verse expuesto en el Museo Provincial de Salamanca. Fue encontrado durante las excavaciones de la villa romana de Sahelices el Chico (Salamanca), una gran villa señorial del siglo IV-inicios del V, que es continuación de un establecimiento del siglo II, y que presenta materiales de época visigoda (DAHÍ, 2012: 43-44). Los peines, en hueso, madera y marfil, también son relativamente frecuentes en niveles neolíticos, calcolíticos y de la Edad del Bronce de la península ibérica, con usos que van desde el estricto aseo personal hasta el de adorno o de carácter votivo, pero también como símbolos de diferenciación jerárquica o profesional (CASTRO CUREL, 1988). 
incluyendo ejemplares que presentan inscripciones rúnicas sobre la funda (HALL, 1995: 29, Figs. 13 y 44, Figs. 23 y 50, Fig. 28), y más allá de perduraciones y nuevas tipologías que tienden al uso de ejemplares simples. ${ }^{44}$

El hallazgo en contextos de cueva es menos frecuente, aunque muy repartido geográficamente. Así contamos con ejemplos desde Noruega, con un ejemplar de cronología tardomerovingia con inscripciones rúnicas en la cueva de Setrehelleren, tal vez en un contexto ritual (BERGSVIK, 2018: 45), hasta las Islas Británicas, en donde se conocen otros dos ejemplares -de tipologías distintas- en la cueva galesa de Minchin Hole (Gower), para la que se postula su posible uso como taller de producción de estos objetos, y con una cronología de uso entre los siglos II y V (BRANIGAN y DEARNE, 1992: 28 y 42).

Una nómina a la que ahora - de confirmarse- podría sumarse el hallazgo de la Cueva de Guantes. Peines que, por características y contextos, se encuadran «en la antigüedad tardía, de transición entre el mundo tardorromano y la Alta Edad Media, en la que confluyen la tradición romana y las influencias germánicas» (HERRÁEZ MARTín, 2017: 249).

Es en este contexto en el que se recogió el tremís de Égica que aquí estudiamos. ${ }^{45}$ Monedas que, debido a sus peculiares características y circunstancias, así como por su escasez, hacen que numerosos autores consideren que, aunque se trata de ejemplares aislados, o incluso descontextualizados, es esencial su puesta a disposición de los investigadores.

\subsection{Tremís de Égica (687-695)}

Anverso: Busto de perfil del rey Tipo $14 \mathrm{c}$ de Pliego. El busto presenta gorro o casco, ínfula y cetro crucífero en el que se apoya un glóbulo (Fig. 6).

\section{Leyendaentornoalbusto:+IND ${ }^{\nabla}$ NMEGICARX}

Reverso: Palmeta a los dos lados de una cruz sobre tres gradas o peldaños. Alrededor se desarrolla la leyenda: +TOLETOPIVS

\section{Ceca: Toleto (Toledo).}

Peso y medidas: 1,42 gramos y módulo de 19,9 milímetros.

Referencias: Inédita (Variante de PLIEGO, 2009: II, $682 \mathrm{f})$.

Nos encontramos ante una variante de los tipos establecidos por R. Pliego, con la N retrógrada. La tipología de este tremís se corresponde con el Grupo V (A/3-R/2): A establecido por VICO MONTEOLIVA et al (2006: 146) y con el «Toledano B», tipo 14c/cruz sobre gradas en la clasificación de R. Pliego (2009: I, 167-168). Como señala esta autora, se trata de una de las tipologías más utilizadas desde la reforma de Chindasvinto (c. 649) hasta el final del Reino de Toledo (711). En ella se representa en el anverso un busto de perfil, con la cabeza cubierta por una especie de casco y vestido con manto y, tal vez, ínfula, aferrando un cetro crucífero -símbolo externo de su poder- en el que se apoya un glóbulo (VICO MONTEOLIVA, 2006; ARIZA ARMADA, 2014: 183; PLIEGO: 2009). ${ }^{46}$

44. Es frecuente el hallazgo de peines compuestos, fundamentalmente, rotos y reparados que evidencian su largo uso entre los siglos IV y X-XI, como prueba de su importante valor (RIJKELIJKHUIZEN, 2011: 200-201; VITEZOVIC, 2016: 180-182 y 203).

45. El tremís o triente es la tercera parte de la unidad, el solidus aureus de la reforma constantiniana; patrón ponderal seguido en las monedas del Reino de Toledo, si bien con oro de menor ley y progresivamente rebajado en favor de la plata, sobre todo hacia el final del reino (RUIZ TRAPERO, 2004: 185-187; PLIEGO, 2015).

46. Aunque algunos autores opinan que podría tratarse de una representación de la gran cruz procesional, realizada en oro, que tenía incrustada entre los travesaños la reliquia del lignum crucis, y que se utilizaba como elemento central en el ceremonial de partida y de regreso del rey hacia campañas bélicas. La reliquia posiblemente fue enviada por el papa Gregorio Magno al rey Recaredo tras su conversión a la ortodoxia nicena. Este ritual en torno a la cruz y la guerra, de clara raigambre constantiniana, se inculcó en el ámbito bizantino y de ahí en el visigodo y franco (BRONISCH 2006: 396; GARCÍA MORENO 2013: 174; VALVERDE CASTRO 2017: 103105). Diversas fuentes del momento (Juan de Bíclaro, Isidoro de Sevilla, Julián de Toledo e, incluso, la Lex Visigothorum) aluden al cetro como símbolo del poder, existiendo muy posiblemente de manera real un cetro (FRANCISCO OLMOS, 2009: 161). 


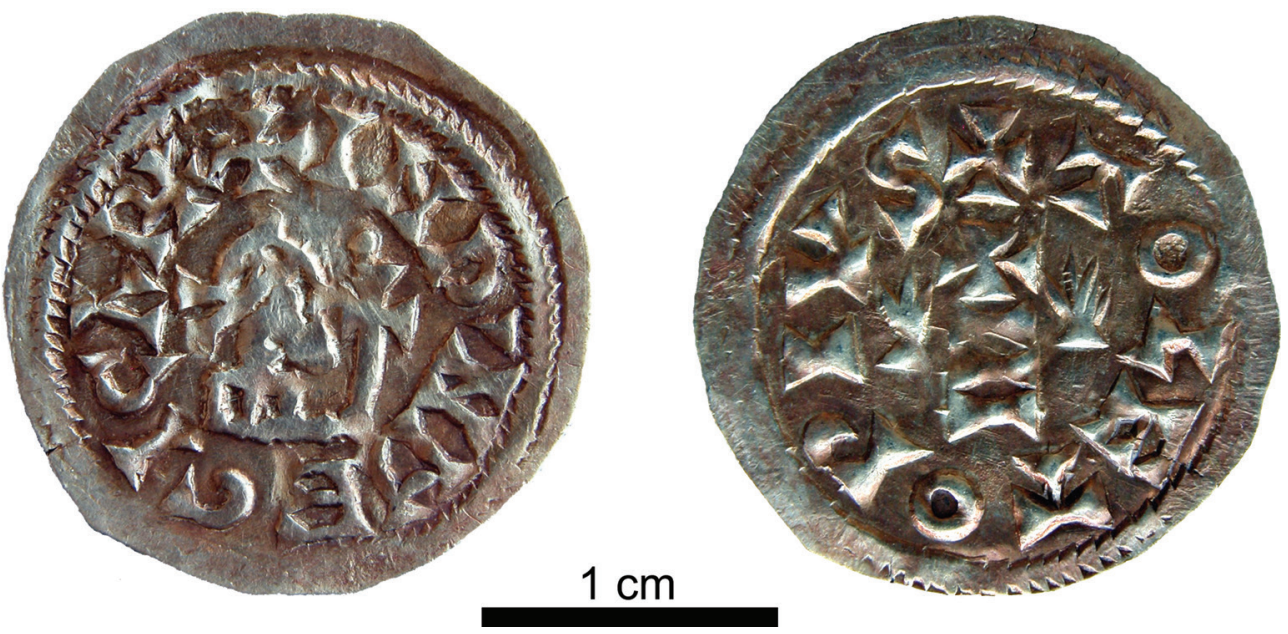

Fig. 6. Tremís de Égica de la Cueva de Guantes.

Este modelo de cetro es muy común -siendo propiamente visigodo y distanciándose así de los imperantes modelos bizantinos- apareciendo en la misma ceca de Toleto en época de Wamba, con el propio Égica (quien además lo utilizó también en las cecas de Narbona, Rodas, Egitania, Elvora y Tude), y en los dos únicos ejemplares conocidos del usurpador Sunifredo (VICO MONTEOLIVA et al, 2006: 521-522; PLIEGO, 2009: I, 167-168). ${ }^{47}$

La ejecución técnica de estos tipos, como es común en la moneda visigoda, es esquemática, si bien ello no puede hacernos olvidar que lo que realmente se buscaba con estas acuñaciones era realzar la identidad política del naciente Estado (MILES, 1952; PLIEGO, 2009: I, 155-174).

Rodeando el busto del rey, en el anverso, nos encontramos una leyenda con el nombre real -en la forma canónica de «EGICA» en nominativo- acompañado de una serie de abreviaturas que hacen referencia a las fórmulas habituales del rey. El título, «REX» del monarca aparece abreviado y con nexo, de una forma que se establece desde las emisiones conjuntas de Chindasvinto y Recesvinto. El resto de la leyenda epigráfica se ajusta a la expresión de la invocación religiosa, introducida desde el reinado de Wamba que llegará hasta Rodrigo, pero anteriormente con Chindasvinto, «IN DEI NOMINE», «IN NOMINE DOMINE» abreviada y separada por un glóbulo (PLIEGO, 2009: I, 177-178, 183-184).

En el reverso nos encontramos el epíteto «PIVS», que se viene utilizando en las monedas visigodas desde Leovigildo, si bien no se encontrará habitualmente hasta la época de Tulga, junto con la leyenda de la ceca "TOLETO».48 Se trata del epíteto más utilizado y extendido, y utilizado casi en exclusividad durante los momentos finales del reino toledano, siendo especialmente usado por las ciudades principales como Toledo (PLIEGO, 2009: I, 178).

47. No parece que exista un patrón regional en la distribución de las monedas visigodas, encontrándose cecas muy dispersas, al mismo tiempo que la escasez de moneda no permite aclarar cómo circuló en numerario visigodo (MARTíN VISO, 2008; PLIEGO, 2020: 204-209). La distribución del monetario entre Égica y Witiza se puede ver en RETAMERO, 2011:220, FIG. 15, conociéndose con posterioridad ejemplares en Chaves (de Emerita), Vega Baja de Toledo (Eliberri), un ejemplar de Emerita sin procedencia identificada, al igual que otros seis de Égica/Witiza (todos ellos en el Museo Nacional de Arte Romano de Mérida) y otro, también sin identificar, de Égica/Witiza, de la ceca de Tarraco (PLIEGO, 2012 y 2020: 194-204). Un simple vistazo a este mapa permite comprobar el vacío que existe en los hallazgos de este monarca en el centro y mitad centro-norte de la península.

48. Es la ceca que cuenta con un mayor número de ejemplares conocidos de entre las emisiones de Égica (PLIEGO, 2009: II, 43), lo que es normal por ser Toledo la principal ceca del reino visigodo, tanto desde el punto de vista político como por el volumen de emisión (FRANCISCO OLMOS y VICO MONTEOLIVA, 2007: 191). 
En el centro, una cruz sobre tres gradas, a cuyos lados se representan sendas palmetas ${ }^{49}$ Este motivo de la cruz sobre gradas - que es una imitación del reverso de las monedas de oro acuñadas por el emperador bizantino Tiberio II Constantino (578-582)-, tiene su origen en una hecho real: la colocación por parte del emperador Teodosio II en el año 420 de una gran cruz enjoyada en la cima del Monte Calvario, y será introducido en la moneda visigoda por Leovigildo -muy probablemente hacia 581-582 en el ámbito geográfico fiel al monarca durante el enfrentamiento con su hijo-, aunque se irá generalizando como uno de los reversos más característicos desde Recesvinto hasta los momentos finales del reino toledano, si bien desaparecerá con diversos monarcas (GRIERSON, 1993: 95-99; FRANCISCO OLMOS y VICO MONTEOLIVA 2007: 185; FRANCISCO OLMOS, 2009: 139-140; PLIEGO, 2009: I, 92-94).

Por otra parte, una de las características más destacadas de las acuñaciones de Égica es la de que, desde ahora, se va a ir incrementando la disparidad metrológica, con ejemplares de diverso peso. Se trata de una consecuencia de la reducción en los niveles de contenido de oro, muy apreciable en el propio color de estas monedas, como ocurre en la que aquí presentamos, puesto que, como señala R. Pliego, en algunos ejemplares encontramos tan solo una media de 14 quilates (PLIEGO, 2009: I, 212; II, 43). En efecto, la caída en la ley de la moneda visigoda se produce de forma constante desde Wamba (80\%) y Égica (70\%), agudizándose la caída con Witiza (45\%) e, incluso, al final del reino, llegando algunos ejemplares a menos de un 20\% (FRANCISCO OLMOS y VICO MONTEOLIVA, 2007: 192-193). Esta devaluación de la ley lleva a que existan emisiones casi fundamentalmente de plata en este período, como ocurre durante el reinado de Égica, hecho que se viene poniendo en relación con las dificultades políticas y económicas del estado visigodo (PLIEGO, 2009: I, 206-212). ${ }^{50}$

A diferencia de lo que ocurre con la moneda de época romana, el territorio palentino no presenta abundancia de hallazgos de tremises visigodos. ${ }^{51}$ Por el contrario, los hallazgos de época romana, unas 5.100 piezas, proceden de una gran variedad de yacimientos y a lo largo prácticamente de toda la provincia: campamentos altoimperiales, diversos tipos de núcleos urbanos, yacimientos vinculados a vías de comunicación, villas bajoimperiales y otros núcleos de población de carácter secundario (GÓMEZ BARREIRO, 2012: 212-215).

Sin embargo, pese a esa parquedad de hallazgos, se conocen dos cecas visigodas en este sector, dentro de la Carthaginense: Mave y Saldania. Se trata de dos cecas localizadas en la zona palentina. ${ }^{52}$ En la primera, acuñaron Sisebuto, Sisenando, Chintila y Chindasvinto, y en la segunda lo hicieron Leovigildo, Recaredo I, Witerico, Sisebuto, Suintila y Chindasvinto (BARLETT, 2001; VICO MONTEOLIVA et al, 2006: 182-184; PLIEGO, 2009: I, 116-117). Mave estaría en relación con Maggaviensium, posiblemente el yacimiento en altura fortificado de Monté Cildá, ubicado en el noroeste de

49. Palmas y glóbulos, tanto en el campo como formando parte de la leyenda, son elementos que pueden ser tanto meramente motivos ornamentales como distintivos de las diferentes emisiones (VICO MONTEOLIVA et al, 2006: 132). Por otra parte, las cruces griegas iniciales de las leyendas de anverso y reverso fueron introducidas desde el reinado de Leovigildo.

50. Esta baja ley es la que le confiere a los tremises de época tardía su característica falta de brillo, a resultas del uso de aleación de electro con trazas de cobre, tal y como ocurre con el ejemplar que aquí presentamos.

51. El Museo Provincial de Palencia tiene entre sus fondos un conjunto de monedas visigodas de procedencia desconocida, aunque existen muchas probabilidades de que su origen fuera Astudillo. Doce de estos trientes fueron estudiados en el año 1977 por M. Va . Calleja en un trabajo inédito (CALLEJA GONZÁLEZ, 1977), contando con ejemplares de Recaredo (Córdoba), Liuva (Sevilla), Gundemaro (Sevilla), Sisebuto (Tarragona), Recesvinto y Chindasvisto (Sevilla), Wamba (dos de Mérida y uno de Sevilla), Égica (Córdoba), Égica y Wittiza (Córdoba) y Rodrigo (un ejemplar de Egitania y otro de Toledo). Es decir, monedas comprendidas entre el 586 y el 711 en lo que parecía ser un ocultamiento de época de la invasión musulmana. Ahora bien, para Pliego (2009: II, 503-563) se trata de una falsificación. Igualmente, en las cercanías de la iglesia de San Juan de Baños (Baños de Cerrato) se localizó un tremís de Witiza (PLIEGO, 2015: 27 y 43)

52. La ceca de Oliovasio, de la que únicamente se conoce un ejemplar de Witerico, se ha ubicado en la zona palentina, ubicación que, además de dudosa, debe tener en cuenta la posibilidad de que nos encontremos ante una falsificación (MILES, 1952: 138; PLIEGO, 2009: I, 117). 
Palencia en el desfiladero de La Horadada. ${ }^{53}$ La ceca de Saldania ha sido identificada con el alto de La Morterona, en Saldaña (Palencia), un poblado con ocupaciones indígenas, visigoda y medieval, tal vez fortificado, en la frontera con Cantabria, y que se ha postulado que fue ocupado durante las campañas de Leovigildo del 574, pasando a convertirse en un puesto avanzado de la frontera norte visigoda. Ambas localidades se encuentran en las proximidades de la calzada alto-imperial Pisoraca-Flaviobriga que, según el Itinerario de Antonino $(449,4)$ se articulaba como un ramal secundario desde la meseta hacia la costa cantábrica (IGLESIAS GIL y MUÑIZ CASTRO, 1992: 145-162; PLIEGO, 2009: I, 115). La explicación más habitual para estas cecas, ubicadas en asentamientos fortificados en zonas de frontera, es la de conmemoración militar o para el pago de los gastos del ejército ubicados en esta zona que tenían como misión el control de posibles incursiones de los pueblos del norte peninsular (PALOL, 1970: 44; DÍAZ, 1994: 471; BARLETT, 2001: 21; DEL AMO y PÉREZ RODRÍGUEZ, 2006: 125), interpretación no compartida por todos los investigadores (PLIEGO, 2009: I, 102 y 116 117). Ahora bien, la existencia de multiplicidad de cecas visigodas como testimonio de actividad militar, en especial contra los pueblos del norte peninsular, es una hipótesis que viene resquebrajándose durante los últimos años, puesto que nuestra visión sobre la evolución de estos pueblos desde la efectiva romanización ha variado enormemente y, en el paradigmático caso de la Gallaecia, su relación con una organización de carácter administrativo y una vinculación con élites locales en virtud de una economía compleja, que incluye actividades minero-metalúrgicas y un importante comercio oriental a través del puerto de Vigo, se conoce cada vez mejor (DÍAZ, 2004; SÁNCHEZ PARDO, 2014).
Como ha señalado en alguna ocasión Ruth Pliego (2020: 206), el tremís presenta un elevado valor intrínseco, lo que implica no descartar la hipótesis de que podamos considerar los hallazgos aislados automáticamente como fruto de un extravío involuntario, incidiendo en el hecho de que no ha de ser siempre evidente que un patrimonio monetario deba de estar formado por un elevado número de monedas. Y partiendo de estas dos premisas, opina esta investigadora que los ocultamientos de monedas visigodas a partir de Witiza han de ponerse en relación con el clima de inestabilidad del reino toledano tras la muerte de este rey y con la invasión musulmana de 711 . Lo que para esta autora evidencia, además, otra consecuencia más: «un uso relativamente extendido del tremís en un contexto en el que todas las clases sociales desean y en algún momento pueden acceder al mismo, aunque su circulación debió estar ligada principalmente a las élites» (PLIEGO, 2015: 18 y 45). ${ }^{54} Y$ es así como el hallazgo aislado de una de estas piezas en una cavidad como la Cueva de Guantes puede cobrar sentido.

\section{5.- CONTEXTO HISTÓRICO DE LA CUEVA DE GUANTES}

El reinado de Égica (687-702) fue, al menos en su parte inicial, bastante convulso. Las conjuras nobiliarias características del reino visigodo volvieron a surgir ahora. En concreto conocemos un intento a manos del obispo de Toledo, Sisberto. Sin embargo, la conjura fue neutralizada por el monarca que rápidamente encarceló a los implicados, cuyas acciones fueron contundentemente condenadas por el XVI Concilio de Toledo de 693. El concilio decretó que el obispo toledano fuera depuesto de su sede, condenado a excomunión y destierro

\footnotetext{
53. De Santa María de Mave se conoce una ocultación con diecinueve monedas de bronce que van desde el siglo I (Claudio) hasta el siglo III (Gordiano III) (GÓMEZ BARREIRO, 2012: 220).

54. Independientemente de que su uso estuviera fundamentalmente restringido a los potentes en el marco de una economía de regalo, con usos menores como el pago militar durante las campañas, como elemento fiscal, como pago de transacciones económicas importantes entre comerciantes (PLIEGO, 2015: 37 y 43-45; RETAMERO, 2011: 203). De la importancia que pudo tener el tremís para personas de nivel intermedio desde el punto de vista económico nos habla las noticias ofrecidas por Gregorio de Tours (Hist. III, 13) sobre el rescata de unos guerreros de la fortaleza de Marlhac que se realizó entregando uno por cabeza, o como en tiempos de hambruna se llegaba a pedir un triente por un moyo escaso de cereal o medio de vino (Hist. VII, 45).
} 
perpetuo, así como la confiscación de sus bienes, que pasaron al monarca. De igual manera, el concilio fue utilizado por Égica para intentar afianzar su posición mediante purgas contra los miembros de la aristocracia pertenecientes a la facción rival y reforzar las medidas sobre la protección de la figura real y su familia (ORLANDIS, 1977: 278-285; FRANCISCO OLMOS, 2009: 165; DÍAZ, 2014: 1149-1150; POVEDA ARIAS, 2015: 25).

Sin embargo, a los efectos que nos ocupan, la conspiración presenta puntos oscuros. No sabemos el alcance que llegó a tener, si bien algunos autores creen que fue de gran importancia. Y ello hasta el punto de que una moneda acuñada en Toledo, estilísticamente ubicable en estos años, lleva el nombre de Suniefredo (VICO MONTEOLIVA et al, 2006: 521; PLIEGO, 2009: II, 419), un personaje sobre el que existen numerosas lagunas. Tal vez se trate del comes scanciarium et dux que firmó las actas del XIII Concilio de Toledo de 683. La existencia de esta moneda ha llegado a plantear la posibilidad de que, aliado con Sisberto, se hizo ungir por éste en Toledo, llegando a controlar la ciudad el suficiente tiempo como para poder acuñar moneda con su nombre (GARCÍA MORENO, 2013: 156-184; DÍAZ, 2014: 1150-1154).

Sin embargo, esta hipótesis plantea muchos problemas: por una parte, el plazo de tiempo suficiente para la acuñación, cuando sabemos que la conjura fue rápidamente controlada, y por otra parte, el que Suniefredo no aparezca entre los condenados en la detallada relación del XVI Concilio de Toledo (FRANCISCO OLMOS, 2009: 166). Lo que lleva a una parte de los investigadores a plantearse que este personaje no se vio envuelto en esta sublevación. Así, Suniefredo sería un alto cargo del palacio real -o tal vez un duque provincial- bajo el reinado de Égica, que hacia 700-702 llegaría a hacerse con el poder en Toledo, acuñando moneda, pero que no estuvo implicado en la conjura de Sisberto. Esta hipótesis parte de las escasas noticias que nos informan sobre el hecho de que, hacia el final del reinado de Égica, se produjeron numerosas epidemias de peste y un escenario de tensiones sociales que habrían creado un clima propicio para una rebelión nobiliaria. Los partidarios de esta hipótesis creen que la mejor prueba de que esto es lo que ocurrió se encuentra en la circunstancia de que el rey Égica promulgó la ley sobre la huida de siervos desde Córdoba en el año trece de su reinado (700), como consecuencia de encontrarse aquí refugiado ante el momentáneo triunfo de la rebelión y la pérdida de control de la capital hasta que esta fue recuperada tras sofocar la revuelta (FRANCISCO OLMOS Y VICO MONTEOLIVA, 2007: 194; FRANCISCO OLMOS, 2009: 166). Pero lo cierto es que, por una parte, no parece que podamos identificar a Suniefredo con el firmante de las actas del XIII Concilio de Toledo y, por otro lado, las estancias de Égica (y Witiza) fuera de Toledo parece que pueden ser explicadas en el seno de la itinerancia de sus cortes (GARCÍA MORENO, 2013: 164-165; VALVERDE CASTRO, 2017: 126-143). También últimamente se ha incidido en que, lejos de ser un rey débil, el intento de rebelión de Sisberto significó un auténtico punto de inflexión en el fortalecimiento del poder monárquico de Égica y en su definitiva emancipación de la tutela del bando de Ervigio (POVEDA ARIAS, 2015: 25-26). L.A. García Moreno ha propuesto recientemente llevar la revuelta de Suniefredo al marco de la guerra civil que se produjo tras la muerte de Witiza y en la que se enfrentaron por el poder, al menos, tres bandos nobiliarios diferentes, basándose para ello en los datos numismáticos, liderados cada uno por un alto dignatario que se llegó a proclamar rey. Así tendríamos a Rodrigo, que en su levantamiento controlaría la Bética; Agila II, que como rey controlaría los ducados nororientales de la Tarraconense y Narbonense hasta el 713; y un tercer bando liderado por Suniefredo, que también como rey dominó, por lo menos, Toledo, y que sería el primero en desaparecer del panorama político, muy posiblemente derrotado por Rodrigo (GARCÍA MORENO, 2013: 156-184).

En cualquier caso, las consecuencias de la mayoría de los enfrentamientos y guerras civiles en la parte final del reino toledano tuvieron escasa o nula incidencia en los territorios 
cantábricos como para justificar una situación que conllevara el ocultamiento de la Cueva de Guantes. Podríamos encontrarnos con dos excepciones. Égica se vio obligado a realizar una serie de campañas militares contra los francos que hacían incursiones en los territorios que el reino toledano mantenía en el mediodía de Francia entre el verano del 688 y el invierno del 690 (al poco de acceder al trono y lapso, creemos, demasiado corto para que sus monedas circularan en un espacio tan periférico como el de la montaña palentina), y otra posiblemente hacia el 693 (VALVERDE CASTRO, 2017: 125-127)..$^{55}$ Otra cosa es la campaña que el rey Rodrigo realizó desde Toledo contra el territorio de los vascones (posiblemente aliados de Agila II), y, más concretamente, dirigiéndose hacia Pompaelo, en el verano del 710 o en la primavera del 711, en donde debió transitar por las vías romanas, relativamente cerca de nuestro territorio, aunque desconocemos su itinerario (GARCÍA MORENO, 2013: 125-184; VALVERDE CASTRO, 2017: 161-169).

En consecuencia, tendremos que esperar a la invasión musulmana para encontrar un mayor protagonismo de campañas militares que, a través de las antiguas vías romanas -en especial gravitando desde la que desde Burdigala transcurría por Caesaraugusta y se dirigía hacia Asturica Augusta-, se aproximaron al área geográfica en la que se enclava la Cueva de Guantes. Si bien las fuentes musulmanas, que son las que nos informan de estas campañas, son contradictorias en algunas ocasiones y presentan serios problemas de credibilidad en otras (MAílLO SALGADO, 2011: 36-39), existe un cierto consenso entre los investigadores en conceder credibilidad -siempre partiendo de una cierta subjetividad en su uso, como reconoce P. Chalmeta (1994: 157)- a las circunstancias en las que se produjeron las campañas musulmanas en el norte de España.

Las operaciones musulmanas que pudieron provocar la ocultación de la Cueva de Guantes pueden ser dos. ${ }^{56}$ La primera de ellas es la que, entre el otoño del 711 y el verano del 712, llevó a cabo el ataque, proveniente desde Toledo, y toma por parte del propio Tariq de la importante ciudad fortificada de La Peña de Amaya, de facto capital de la zona cántabra. El objetivo de esta campaña, según las fuentes musulmanas, era la obtención del botín de los magnates visigodos aquí refugiados, si bien posiblemente nos encontremos ante la intención de desmontar el aparato militar y administrativo visigodo en el norte $y$, consecuentemente, para ello era necesario la toma de las capitales, por lo que tras Amaya el siguiente objetivo lógico era Astorga, al mismo tiempo que controlar la antigua vía romana que unía Astorga con Zaragoza (SÁNCHEZ ALBORNOZ, 1972: 432433; QUINTANA LÓPEZ, 2008: 257; QUINTANA LÓPEZ, 2017)..$^{57}$

El segundo momento de acciones bélicas que podrían explicar el ocultamiento de la Cueva de Guantes es cuando hacia 713-714 se inicia la campaña que lleva a ocupar Zaragoza por parte de los musulmanes (a la que llegaron siguiendo la vía romana de Emerita a Caesaraugusta); desde aquí, Tariq se dirigió hacia el noreste, saqueando ciudades como Huesca y Lérida y tal vez conquistando Tarragona, en su lucha contra Agila II; mientras que Musa se dirigió hacia Pamplona, para a continuación ir hacia Yilliqiya (la región galaico-astur-leonesa), cuyos habitantes se someterían mediante pactos, ocupando Lugo, tras pasar por Tierra de Campos sin que se mencionen acciones bélicas en esta última zona

55. Campañas que se recogen por parte de Julián de Toledo (Progn. Praefatio, 8-83) y por las dos versiones de la Crónica de Alfonso III (Rot. 4; Ad Seb. 4).

56. Existen discrepancias musulmanas entre las fuentes al establecer tanto los itinerarios como los protagonistas de esas conquistas, lo que confiere al proceso una cierta confusión, por lo que habitualmente se ha tendido a realizar una reconstrucción ecléctica del proceso, como la realizada por P. CHALMETA (1994), criticada por otros autores, como F. MAÍLLO (2011), y que difiere de otras reconstrucciones clásicas como la de SÁNCHEZ ALBORNOZ (1972).

57. Campaña relatada principalmente por JIMÉNEZ DE RADA (Rebus, 1, I, III, C. XXIV), que coincide con diversas fuentes árabes (CHALMETA, 1994: 157-159). 
(SÁNCHEZ ALBORNOZ, 1972: 413-458; CHALMETA, 1994: 181-192; SALVATIERRA y CANTO, 2008: 29-30).58 En esta campaña ya no se menciona Peña Amaya, posiblemente porque desde la acción de Tariq de 712 estaba ocupada por una guarnición musulmana (QUINTANA LÓPEZ, 2008: 257).

Desde Zaragoza (o tal vez desde Tarragona, si es que llegó hasta aquí), Musa se aprestaría a la realización de la última campaña contra el noroeste peninsular. Para Sánchez Albornoz se pudieron seguir en esta campaña dos rutas alternativas que seguían dos vías romanas que llevaban de Caesaraugusta a Asturica. La primera iría hacia el Duero, avanzando por Numantia, Uxama y Clunia, pasando por la zona palentina o seguir por el Duero hasta Tudela, en las cercanías de Valladolid, y a través de la Tierra de Campos, seguir avanzando hacia Benavente y Astorga. La segunda opción - la preferida por el insigne medievalista- pasaría por remontar el curso del Ebro hasta Vareia, junto a Logroño, cruzando La Rioja, pasando por Cerezo hasta la Bureba, Briovesca y Asturica Augusta, y previamente para ello por Sasamón, Osorno, Carrión y Sahagún, Lancia y Viadangos, para desde aquí llegar finalmente a Lugo (SÁNCHEZ ALBORNOZ, 1972: 449-455). Sería desde aquí desde donde se iniciarían las campañas hacia el norte, tal vez a comienzos del verano de 714 (SÁNCHEZ ALBORNOZ, 1972: 475; CAMINO MAYOR et al, 2010: 18; CHALMETA, 1994: 158).

La realidad de estas campañas, tan discutidas en algunos casos por la problemática de las fuentes árabes, es en realidad irrelevante para nuestros propósitos pues, bien mediante expediciones militares efectivas, bien mediante el pacto de rendición, lo cierto es que se produjo el control del territorio del norte peninsular por parte de los musulmanes en unas fechas tempranas, lo que necesariamente conllevó la llegada de tropas y la consabida incertidumbre de la población ante los acontecimientos. Este hecho viene refrendado por la cada vez más abundante evidencia de hallazgos arqueológicos relacionados con estos primeros momentos de la conquista en el norte y en el noroeste peninsular y su clara vinculación con las antiguas vías romanas. Así, conocemos varias ocupaciones tempranas, posiblemente relacionadas en algunos de los casos con guarniciones bereberes, constatadas mediante cerámicas andalusíes tempranas, como en el interior amurallado de León, en la fortificación de Puente Castro (León), en Lancia (Léon), una fortificación relacionada con las campañas de 878-883 y, tal vez, en Astorga y Zamora. Pero también en otras ciudades, castra y castella del norte peninsular (Tiermes, Clunia, Numancia, Bernardos, Iscar o Castrogonzalo). ${ }^{59}$ Así como de Portugal, como Coímbra y Conimbriga (GUTIÉRREZ GONZÁLEZ, 2019: 264-265). Especialmente significativo es el caso de Lugo por su importancia en el control del área noroeste de la península que las propias fuentes le atribuyen, y en donde se ha documentado un medio dinar acuñado en África en los primeros momentos de la conquista junto con obras en las torres de las puertas principales, que podrían relacionarse con época emiral (ORTEGA, 2018: 116; GUTIÉRREZ GONZÁLEZ, 2019: 264). Pero también con evidencias de ocupación de áreas rurales atestiguadas a través de hoyos-silo y cerámicas pintadas en villas y asentamientos rurales tardorromanos de la Meseta, como Matallana (Valladolid), en la basílica de Marialba (Léon) y, muy evidentemente, en la villa romana de Cimanes de la Vega (León) (GUTIÉRREZ GONZÁLEZ, 2019: 265). De este último yacimiento procede un dinar de indicción XI (tal vez XII), es decir, entre el 713-715 d.C., acuñado en Spania (Span), y con la invocación únicamente en caracteres latinos; una acuñación de las primeras emisiones realizadas en la península por los musulmanes, denominadas «transicionales»

58. Para L.A. García Moreno, esta campaña de Musa contra la zona de Lugo nunca habría existido, entre otros motivos por la rendición mediante pacto de todos los territorios del noroeste en momentos previos, lo que haría innecesaria una expedición militar (GARCÍA MORENO, 2013: 426- 434 y 446-453).

59. Ciudades que, al menos en parte de ellas, se ha podido comprobar su continuidad de funcionamiento, incluso con una cierta vitalidad durante la Tardoantigüedad (DOHIJO, 2010). 
(BALAGUER, 1976; REGUERAS y RODRÍGUEZ, 2017: 21-24). .0

El dinar de indicción de Cimanes resulta especialmente significativo en este proceso de ocupación de los espacios del noroeste por parte musulmana de una manera temprana y no demasiada conflictiva, pues marca unas pautas en el mismo: ocupación de un lugar de origen romano que parece seguiría siendo ocupado de alguna manera hasta el siglo VIII d.C., «en un enclave viario de fácil acceso a Astorga, a través de la vía de la Plata y a León, por el valle del Esla» (REGUERAS y RODRÍGUEZ, 2017: 22). De esta manera, se viene a confirmar algo que hace algunos años ya parecía evidente, que los hallazgos de moneda musulmana del primer momento de la conquista se concentran en asentamientos situados a lo largo de las vías romanas, como se ha constatado claramente en el noreste peninsular y sur de Francia a lo largo de la antigua vía Domitia, evidenciándose de esta manera la ruta seguida por los musulmanes en su camino para las incursiones en territorio franco (SÉNAC et al, 2014). ${ }^{61}$

En este mismo sentido, los recientes descubrimientos en la Cordillera Cantábrica de una serie de fortificaciones que cortan las antiguas vías romanas de acceso al territorio asturiano, El Muru en la vía de La Mesa y el Homón de Faro en la vía de La Carisa, y en el cántabro, con El Cotero del Medio, en la vía de El Escudo, se han interpretado como clausuras de protección ante el avance musulmán (CAMINO MAYOR et al, 2010). ${ }^{62}$ Unas fortificaciones similares a las conocidas en los pasos pirenaicos de Cize e Ibañeta, cercanos a Roncesvalles, o a las de los pasos orientales de Perthus y Panissars en la vía Domitia, y que fueron utilizadas desde el siglo $\mathrm{V}$ d.C. hasta las campañas musulmanas contra los francos (GUTIÉRREZ GONZÁLEZ, 2019: 266).

\section{6.- CONCLUSIONES}

La Cueva de Guantes, por sus características topográficas, accesibilidad y escasa entidad de los hallazgos, parece que podría encuadrarse en uno de los más característicos usos de las cavernas durante la tardoantigüedad: el de refugio ocasional en relación con labores agropecuarias realizadas en sus proximidades. ${ }^{63}$ Una cueva que, por otro lado, se encuentra en las proximidades de diversas vías de comunicación, tal y como hemos visto.

Dado el contexto particular del hallazgo del tremís de Égica, en consecuencia, no deberíamos pensar únicamente en la posibilidad de un extravío sino que también podría explicarse, no como una pérdida, sino como un ocultamiento intencionado que no llegó a recuperarse, posiblemente por una situación de peligro. En este sentido, se podría plantear la posibilidad de que nos encontrásemos ante la problemática de la ocupación musulmana del norte peninsular. Bien un personaje venido desde otro lugar, tal vez gracias a la cercanía de la cueva con las vías de comunicación y su fácil acceso para un viajero, o bien un local con una cierta capacidad económica (la presencia del peine podría apuntar

60. El contenido aurífero de estos dinares es elevado, y los análisis de las aleaciones evidencian que los dinares epigráficos latinos se produjeron con metal procedente de moneda visigoda (BALAGUER, 1976; JONSON, 2014: 343-345). De hecho, es muy poco frecuente el que aparezcan junto con moneda visigoda, como en el conjunto de monedas (que no un tesoro) de Burguillos del Cerro (Badajoz), formado por varias monedas romanas de cobre, visigodas de oro y árabes de plata (MARTÍNEZ CHICO y GONZÁLEZ GARCÍA, 2017: 296)

61. Se ha venido defendiendo el que estas monedas son una de las más importantes evidencias de la llegada temprana musulmana a una determinada área geográfica, tanto por su cronología como por el hecho de ser realizadas por talleres móviles que acompañarían a las tropas, para pagar con ellas los impuestos en oro que se les imponían (CANTO, 2010: 136). Si bien otros autores difieren de esa movilidad, apostando por un taller centralizado en Hispalis. Sobre estas cuestiones, BALAGUER, 1976.

62. Aunque las dataciones radiocarbónicas permitan otras posibilidades cronológicas.

63. Lo que no descarta el que, en algún momento, pudiera servir como taller artesanal de manera ocasional, como podría indicar el fragmento del posible peine sin terminar. Un taller de peines se ha querido identificar en la galesa cavidad de Minchin Hole (BRANIGAN y DEARNE, 1992: 28 y 42). Más próximo a nuestro territorio se han interpretado las cuevas vascas de Arrikrutz y de Iritegi como cuevas de carácter artesanal por su actividad metalúrgica (QUIRÓS y ALONSO, 2007-2008: 1138). 
igualmente en esa dirección), buen conocedor de la cueva por su uso habitual como refugio temporal en las diversas labores agropecuarias, ante la inseguridad de la situación que, de hecho, conllevó el que la moneda nunca fuese recuperada.

En esta línea explicativa, se conocen una serie de ocultaciones de cruces y coronas así como de moneda visigoda, en especial aquellas cerradas con emisiones de Witiza acuñadas en solitario entre el 702 y el 710 , que se vinculan con el avance musulmán: como el tesorillo de la mina de lapis specularis de La Condenada (Osa de la Vega, Cuenca), el tesorillo de la mina de Los Morceguillos (Alconchel de la Estrella, Cuenca), y en la Grotte de Montau (Corbère-les-Cabanes, Pyrénées-Orientales), ocupada en las primeras décadas del siglo VIII d.C., se localizó una moneda de Witiza y otra de Agila II junto con diversos objetos, o el tesorillo de Abusejo (Ciudad Rodrigo, Salamanca) (PLIEGO, 2015: 33 y 22; ORTEGA, 2018: 94 y 98). ${ }^{64}$ Estos ocultamientos han sido interpretados como evidencia de la amenaza que sintieron ante la invasión islámica los miembros de las aristocracias laicas y eclesiásticas, a todos los niveles, tal y como indicaría el diferente grado de riqueza que representan los distintos ocultamientos. Es significativo al respecto el tesoro de Abusejo, formado inicialmente en la Baetica, y ascendiendo en bloque por la vía que unía Mérida con Astorga, con fecha de cierre cercana al 711 como consecuencia de ese sentimiento de inseguridad ante la invasión musulmana (MARTÍN-ESQUIVEL y BLÁZQUEZ-CERRATO, 2018: 152-154). Aunque también se ha pretendido interpretar estos testimonios como posibles ocultamientos de botín por parte de bereberes, tal y como se denuncia en la Crónica del 754 (63), antes del reparto oficial que incluía el quinto para el Estado de Damasco (ORTEGA, 2018: 94).
La moneda de la Cueva de Guantes, si bien se trata de un hallazgo aislado y perteneciente a un momento ligeramente anterior a las acuñaciones de cierre (desde el reinado de Witiza) que se ponen en relación con los ocultamientos ante el avance musulmán, creemos que debe responder a esta circunstancia. ${ }^{65}$ De hecho, es significativo que, como una buena parte de los que así se interpretan, aparezca en un contexto de cueva o mina.

Una posible explicación -sin descartar una mera pérdida accidental- pudiera ser la de que se tratase del principal «capital» de un pequeño potentado local, y en ese sentido se explicaría que contase con un tremís únicamente, atesorado por su propietario desde tiempo antes, en un área geográfica en la que no sería sencillo que llegasen acuñaciones de oro como esta y que no contaría, en consecuencia, con las más cercanas a la invasión, como sí parece que ocurrió más hacia el sur de la provincia, tal y como evidenciaría el ejemplar de Witiza encontrado cerca de San Juan de Baños (PLIEGO, 2015: 27 y 43). ${ }^{66}$ Igualmente, sería posible que se trate de una pérdida u ocultamiento por parte de viajeros ocasionales (no olvidemos la cercanía de las vías de comunicación) o de los frecuentadores de la cueva. Pero la existencia en el mismo contexto de objetos, incluso de cierto prestigio como el peine, que nos hablan de un uso continuado de la cueva, podría hacer pensar que nos encontramos ante un posible ocultamiento local más que de un foráneo. Y es que cada vez es más frecuente entre los investigadores la idea de que la moneda visigoda de oro no se limitaba a un circuito concentrado en los ámbitos urbanos, sino que también lo haría en los ámbitos rurales, incluso en algunos casos de forma preeminente, como en el norte de la Lusitania o el valle del Duero, utilizándose en distintos niveles sociales, lo que, a su vez, denota la existencia de elites locales (MAROT, 2001: 149-150; MARTÍN VISO, 2008; PLIEGO, 2015).

64. Para Abusejo véanse ahora los comentarios de PLIEGO, 2020: 207-209.

65. Por otro lado, en la Cova del Parco (Alós de Balaguer, Lérida), también en un medio de montaña, se documentó únicamente un triente de Égica (ORTEGA, 2018: 98).

66. Independientemente del falso conjunto de Astudillo que, de ser auténtico, estaría reflejando un típico ocultamiento a consecuencia de la invasión (CALLEJA GONZÁLEZ, 1977). 


\section{BIBLIOGRAFÍA}

ABÁSOLO Álvarez, José Antonio. (1973): Dos miliarios romanos inéditos en Padilla de Abajo, provincia de Burgos. Durius 1-2, 349-350.

ADROHER, Andrés María; LÓPEZ MARCOS, Antonio; PACHÓN ROMERO, Juan Antonio (2002): Granada arqueológica. La cultura ibérica. Granada: Universidad de Granada.

AGUILERA ARAGÓN, Isidro. (1996): "La ocupación tardorromana de la cueva del Moro". Bolskan 13, 133-137. Recuperado de: http:// revistas.iea.es > index.php > BLK > article > download.

AJA SÁNCHEZ, José Ramón. (2008): "Cantabria en la Antigüedad tardía” en J.R. Aja Sánchez, M. Cisneros Cunchillos, J.L. Ramírez Sádaba (coords.), Los cántabros enla antigüedad: la historia frente al mito, pp. 191-228. Santander: Universidad de Cantabria.

ÁLAMO, José del. (1950-1951): Colección diplomática del monasterio de San Salvador de Oña. Madrid: CSIC.

ALCALDE CRESPO, Gonzalo. (1995): Aguilares, otra historia. Aguilar de Campoo: Ayuntamiento de Aguilar de Campoo.

ALFARO GINER, Carmen. (1997): El tejido en época romana. Madrid: Arco

ALONSO ÁVILA, Ángeles (1985): "En torno a la visigotización de la provincia palentina". Publicaciones de la Institución Tello Téllez de Meneses, 53, pp. 267-295. Recuperado de: https://dialnet.unirioja.es/servlet/articulo?codigo=2489181

ÁLVAREZ LLOPIS, Elisay PEÑA BOCOS, Esther (2005): "Límitesy "Fronteras" en el Norte Peninsular. Aproximación cartográfica al territorio de Cantabria entre el mundo antiguo y el medieval". Espacio, Tiempo y Forma. Serie III. Historia Medieval 18, pp. 13-25.Recuperado de: http://e-spacio.uned.es/fez/view/bibliuned:ETF26703C 3D-FFB6-C9BD-5123-4B83F46406B8.

ÁlVAREZ PALENZUELA, Vicente Ángel (1970): El Priorato de San Román de Entrepeñas. Memoria de licenciatura inédita. Valladolid: Universidad de Valladolid.

ÁLVAREZ SACHIS, Jesús y CARDITO ROLLÁN, Luz María (2000): Comisión de antigüedades de la Real Academia de la Historia. Catálogo de Castilla y León. Madrid: Real Academia de la Historia.

ARIAS, Pablo; ONTAÑÓN, Roberto; GUTIÉRREZ CUENCA, Enrique; HIERRO GÁRATE, José Ángel; ETXEBERRIA, Francisco; HERRASTI, Lourdes y UZQUIANO, Paloma (2018): "Hidden in the depths, far from people: Funerary activities in the Lower Gallery of La Garma and the use of natural caves as burial places in early medieval Cantabria, northern Spain". En K.A. Bergsvik y M. Dowd (eds.), Caves \& Ritual in Medieval Europe, AD 500-1500, pp. 133-151. Oxford: Oxbow. https://doi.org/10.2307/j.ctvh1dnwt.12

ARIÑO GIL, Enrique (2013): "El hábitat rural en la península ibérica entre finales del siglo IV y principios del VIII: un ensayo interpretativo". Antiquité Tardive 21, pp. 93-123. https://doi. org/10.1484/J.AT.5.101406

ARIÑO GIL, Enriquey DÍAZ MARTínEZ, Pablo.C. (2004): "Poblamiento y organización del espacio. La Tarraconense pirenaica en el siglo VI". Antiquité Tardive 11, pp. 223-237. https://doi.org/10.1484/J. AT.2.300260
ARIZA ARMADA, Almudena (2014): "Poder y legitimidad. Signos y símbolos en la moneda medieval de la Península Ibérica". Hesperia, Culturas del Mediterráneo, Año IX, Vol. I, pp. 181-199.

ARROYO, Luis Antonio (s. f.) El camino de Santiago entre Herrera de Pisuerga y Carrión de los Condes. Herrera de Pisuerga (inédito).

ASHBY, Steven. P. (2006): Time, trade and identity: bone and antler combs in Northern Britain C.AD 700-1400. 2 Vols. PhD thesis, University of York. Recuperado de: http://etheses.whiterose.ac.uk/id/ eprint/14191

BALAGUER I PRUNES, Ana Mạ. (1976): Las emisiones transicionales árabe-musulmanes de Hispania. Madrid: Asociación Numismática Española, CSIC.

BARLETT, Petter (2001): "Mave and Saldania, two new mints of the coinage of Sisebut from Northern Carthaginensis in the present province of Palencia". Gaceta Numismática 143, pp. 17-21.

BARRAL I ALTET, Xavier (1976): La circulation des monnaies Suèves et Visigothiques. Contribution à l'histoire économique du royaume visigot. München.

BASTERRA ADÁN, Vicente (2009): "Las antiguas vías de comunicación de la montaña palentina”. Publicaciones de la Institución Tello Téllez de Meneses 80, pp. 109-149.

BELTRÁN DE HEREDIA, Julia (2001): De Barcino a Barcinona (siglos I-VIII). Los restos arqueológicos de la Plaza del Rey de Barcelona. Barcelona.

BERGSVIK, Knut Andrea (2018): "The perception and use of caves and rockshelters in Late Iron Age and medieval western Norway, c. AD 550-1550". En K.A. Bergsvik y M. Dowd (eds.), Caves \& Ritual in Medieval Europe, AD 500-1500, pp. 32-62. Oxford: Oxbow. https:// doi.org/10.2307/j.ctvh1dnwt.7

BERROCAL-RANGEL, Luis; MARTíNEZ SECO, Paz y RUIZ TRIVIÑO, Carmen. (2002): El Castiellu de Llagú. Un castro astur en los orígenes de Oviedo. Madrid: Real Academia de la Historia.

BLÁZQUEZ y DELGADO AGUILERA, Antonio (1920): Vías romanas de Carrión a Astorga y de Mérida a Toledo. Madrid.

BOHIGAS ROLDÁN, Ramón y GUTIÉRREZ PÉREZ, José (2012): "Avance sobre las cerámicas del Castellar (Villajimena, Palencia)”. En Fernández Ibáñez, C., Bohigas Roldán, R. (eds.), en Durii Regione Romanitas. Estudios sobre la Romanización del Valle del Duero en Homenaje a Javier Cortes Álvarez de Miranda, pp. 411420: Palencia-Santander: Diputación de Palencia e Instituto Sautuola.

BRANIGAN, Keith y DEARNE, M.J. (1992): Romano-British Cavemen. Cave Use in Roman Britain. Oxford: Oxbow.

BRONISCH, Alexander Pierre (2006): Reconquista y Guerra Santa. La concepción de la querra en la España cristiana desde los visigodos hasta comienzos del siglo XII. Granada: Universidad de Granada.

CADIÑANOS BARDECI, Inocencio (2002): "Fortificaciones y castillos en los siglos románicos". En J.L. Huerta Huerta (ed.). Palencia en los siglos del Románico, pp. 167-200. Aguilar de Campoo: Fundación Santa María la Real.

CALLEJA GONZÁLEZ, Ma․ Valentina (1977): "Monedas visigodas del Museo Arqueológico Provincial de Palencia”. Documento 
conservado en Centre de documentació de l'Institut Català d'Arqueologia Clàssica (ICAC). Fons Dr. Pere de Palol, número de registre 019714.

CAMINO MAYOR, Jorge; VINIEGRA PACHECO, Yolanda y ESTRADA GARCíA, Rogelio (2010): "En las postrimeras montañas contra el sol poniente. Las clausuras de la Cordillera Cantábrica a finales del Reino visigodo frente a la invasión islámica". En J.I. Ruiz de la Peña Solary J. Camino Mayor (coords.), La Carisa y La Mesa. Causas políticas y militares del origen del Reino de Asturias, pp. 3-31. Oviedo: Asociación de Amigos de la Carisa.

CANTO GARCÍA, Alberto J. (2010): "Las monedas de la conquista". En 711. Arqueología e Historia entre dos Mundos. Volumen I. Zona Arqueológica 15, pp. 135-143. Madrid: Museo Arqueológico de la Comunidad de Madrid.

CARDITO ROLLÁN, Luz Mạ. (1996): "Las manufacturas textiles en la Prehistoria: Las placas de telar en el Calcolítico peninsular". Zephyrus 49, pp. 125-145

CARMONA ÁVILA, Rafael (1990): "Inhumaciones de época visigoda en "El Arrimadizo" (Término Municipal de Priego de Córdoba)". Antiqvitas 1, pp. 25-31.Recuperado de: https://dialnet.unirioja. es/servlet/articulo?codigo $=270978$.

CASTRO CUREL, Zaida (1985): "Pondera. Examen cualitativo, especial y su relación con el telar con pesas”. Empúries, 47, pp. 230-253.

CASTRO CUREL, Zaida (1988): "Peines prehistóricos peninsulares". Trabajos de Prehistoria 45 (1), pp. 243-258. https://doi. org/10.3989/tp.1988.v45.i0.613

CASTRO PRIEGO, Manuel (2016): "Absent Coinage: Archaeological Context and Tremisses on the Central Iberian Peninsula in the 7th and 8th Centuries AD". Medieval Archaeology 60 (1), pp. 27-56. https://doi.org/10.1080/00766097.2016.1147784

CENTENO CEA, Inés Mạa; PALOMINO LÁZARO, Ángel L. y NEGREDO GARCÍA, María (2016): "Transición y continuidad época romana-Alta Edad Media en el sur de Palencia: los contextos cerámicos de la $2^{\mathrm{a}}$ mitad del siglo V de Soto de Cerrato". En A. Vigil-Escalera Guirado, J.A. Quirós Castillo (dir.), La cerámica de la Alta Edad Media en el cuadrante Noreste de la Península Ibérica (siglos V-X). Sistemas de producción, mecanismos de distribución y patrones de consumo, pp. 255-277. Bilbao: Universidad del País Vasco.

CEPEDA OCAMPO, Juan José (2004): "Peña Cutral (Cantabria). La vía y los campamentos romanos." Kobie (Serie Anejos). Homenaje al Prof. J. Mª Apellániz, 6. I, pp. 391-402.

CHALMETA, Pedro (1994): Invasión e islamización. La sumisión de Hispania y la formación de al-Andalus. Madrid: Maphre.

CHRISTIE, Neil (2006): From Constantine to Charlemagne. An Archaeology of Italy AD 300-800. Aldershot: Ashgate. Recuperado de: https://books.google.es/books?id=eifJKt02ELkC\&printse$c=$ frontcover\&dq $=$ CHRISTIE, $+N$. $+2006 .+$ From + Constantine + to+Charlemagne. + An+Archaeology+of+ltaly+AD+300-800.+Aldershot.\&hl=es\&sa=X\&ved=0ahUKEwi6xpCWhNnoAhXnyYUKHe2GD-MQ6AEIJzAA\#v=onepage\&q=CHRISTIE\%2C\%20 N.\%202006.\%20From \%20Constantine $\% 20$ to \%20Charlemagne. $\% 20$ An\%20Archaeology $\% 20$ of\%20ltaly\%20AD\%20 300-800.\%20Aldershot.\&f=false.

COLOMINAS, Lidia (2020): Siguiendo los pasos de la trashumancia en la antigüedad. Recuperado de: https://fundacionpalarq.com/ trashumancia-en-la antiguedad/?utm_source=Enero20\&utm_ medium=anal\%C3\%ADticas.

CORTÉS ÁLVAREZ DE MIRANDA, Javier y RÍOS SANTOS, Domiciano. (1979): "Aportación a la carta arqueológica de Palencia: Yacimientos en la margen izquierda del Río Carrión, entre Saldaña y La Serna". Publicaciones de la Institución Tello Téllez de Meneses 43, pp. 41-60.

CRUZ SÁNCHEZ, Pedro Javier y MARTín RODRÍGUEZ, Eva Ma (2012): "La ocupación medieval del yacimiento de La Aldea y sus niveles fundacionales (Baltanás, Palencia)". En Fernández Ibáñez, C., Bohigas Roldán, R. (eds.), en Durii Regione Romanitas. Estudios sobre la Romanización del Valle del Duero en Homenaje a Javier Cortes Álvarez de Miranda, pp. 421-425. Palencia-Santander: Diputación de Palencia e Instituto Sautuola.

DAHÍ ELENA, Sara (2012): Contextos cerámicos de la Antigüedad Tardía y Alta Edad Media (siglos IV-VIII d.C.) en los asentamientos rurales de la Lusitania Septentrional (Provincia de Salamanca, España). Oxford: BAR International Series 2401, Archeopress. https://doi. org/10.30861/9781407309965

DEL AMO Y DE LA HERA, Mariano y PÉREZ RODRÍGUEZ, Francisco Javier (2006): Guía del Museo de Palencia. Palencia: Junta de Castilla y León.

DERKS, Ton y WOUTER, Vos (2010): "Wooden combs from the Roman fort at Vechten: The bodily appearance of soldiers". Journal of Archaeology in the Low Countries 2-2, pp. 53-77.

DÍAZ MARTINEZ, Pablo. C. (2004): "Acuñación monetaria y organización administrativa en la Gallaecia Tardoantigua". Zephyrus LVII, pp. 367-375. Recuperado de: https://revistas.usal.es/index. php/0514-7336/article/view/5413

DÍAZ MARTINEZ, Pablo. C. (1994): "La ocupación germánica del Valle del Duero: Un ensayo interpretativo". Hispania Antiqva, XVIII, pp. 457-476

DÍAZ MARTínEZ, Pablo C. (2014): "Concilios y obispos en la península ibérica (siglos VI-VIII)». En Chiese Locali e Chiese Regionali nell'Alto Medioevo, Spoleto, 4-9 aprile 2013. Settimane di Studio della Fonzazione Centro Italiano di Studi sull'Alto Medioevo LXI, pp. 10951154. Spoleto: Centro Italiano di Studi Sull'Alto Medioevo.

DIEGO SANTOS, Francisco (1979): "De la Asturias sueva y visigoda". Asturiensia Medievalia 3, pp. 17-73.

DÍEZ HERRERA, Carmen (2008): "Hacia la Edad Media. ¿Advenimiento de nuevas formas de organización social y territorial?". En J.R. Aia Sánchez, M. Cisneros Cunchillos, J.L. Ramírez Sádaba (coords.), Los cántabros en la antigüedad: la historia frente al mito, pp. 265-278. Santander: Universidad de Cantabria.

DIEZ MARTín, Fernando; SÁNCHEZ YUSTOS, Policarpo; GÓMEZ GONZÁLEZ, José Ángel; GÓMEZ DE LA RÚA, Diana; YRAVEDRA SÁINZ DE LOS TORREROS, José y DÍAZ MUÑOZ, Isabel (2011): "La ocupación neandertal en el Cañón de La Horadada (Mave, Palencia, España): Nuevas perspectivas arqueológicas en Cueva Corazón". Munibe 62, pp. 65-85.

DíEZ MERINO, Luis (2001): "El castillo de San Román de Entrepeñas. Santibáñez de la Peña (Palencia)”. Publicaciones de la Institución Tello Téllez de Meneses 72, pp. 45-98. 
DOHIJO, Eusebio (2010): "Evolución y transformación urbana de las ciudades del Alto Valle del Duero durante la Antigüedad Tardía". En A. García (ed.), Espacios urbanos en el occidente mediterráneo (s. VI-VII), pp. 219-228. Barcelona: Toletvm Visigodo.

ESTEBAN DELGADO, Milagros (1990): El País Vasco Atlántico en época romana. San Sebastián: Universidad de Deusto.

FANJUL PERAZA, Alfonso (2011): "Las últimas cuevas. Observaciones en torno a la ocupación histórica de las cuevas astur-leonesas". Arqueología y Territorio Medieval 18, pp. 91-116. Recuperado de: http://www.ujaen.es/revista/arqytm/PDF/R18/R18_7_ Fanjul.pdf. https://doi.org/10.17561/aytm.v18i0.1469

FANJUL PERAZA, A.; ÁLVAREZ PEÑA, Alberto; HIERRO GÁRATE, José María y SERNA GANCEDO, Alis (2010): "El santuariu astur-romanu en cueva d’ El Ferrán (Piloña)”. Asturies 29, pp. 16-23.

FEIJOÓ, Manel (2018): "Christian and Muslim patterns of secular and secular and religious cave use in the Iberian Peninsula in Late Antiquity and the Early Middle Ages (fifth/sixth to eleventh/ twelfth centuries AD)". En K.A. Bergsvik y M. Dowd (eds.), Caves \& Ritual in Medieval Europe, AD 500-1500, pp. 152-164. Oxford: Oxbow. https://doi.org/10.2307/j.ctvh1dnwt.13

FERNÁNDEZ ACEBO, Vigilio; MARTÍNEZ VELASCO, Antxoka y SERNA GANCEDO, Mariano Luis (2010): "Los poblados fortificados de la Edad del Hierro y las estructuras campamentales romanas en Cantabria. Reflexiones sobre el poblamiento, el reparto geográfico y la configuración". En M.L. Serna Gancedo, A. Martínez Velasco y V. Fernández Acebo (coords.), Castros y Castra en Cantabria. Fortificaciones desde los orígenes de la Edad del Hierro a las guerras con Roma. Catálogo, revisión y puesta al día, pp. 588-641. Santander: Acanto.

FERNÁNDEZ CONDE, Francisco Javier (1993-1994). "Lugares de culto en Asturias durante la época de transición”. Asturiensia Medievalia 7, pp. 31-55.

FERNÁNDEZ FLÓREZ, José Antonio (1984): "El "Becerro de las Presentaciones". Códice 13 de la Catedral de León. Un parroquial leonés de los siglos XIII-XV". León y su Historia. Miscelánea Histórica de temas Leoneses. Vol. V, pp. 263-565. León: Centro de Estudios San Isidoro.

FERNÁNDEZ GONZÁLEZ, Alejandro (2015): Evidencias Arqueológicas de la presencia Visigoda en Campoo-Los Valles (574-711 d.C.). Trabajo Final de Máster. Santander: Universidad de Cantabria. Recuperado de: http://hdl.handle.net/10902/7536.

FERNÁNDEZ GONZÁLEZ, Alejandro (2018): "Análisis territorial de la Cantabria meridional en la Antigüedad Tardía: la comarca de Campoo-Los Valles". Hispania Antiqva XLII, pp. 218-248. Recuperado de: https://revistas.uva.es/index.php/hispaanti/article/view/2272. https://doi.org/10.24197/ ha.XLII.2018.218-250

FERNÁNDEZ OCHOA, Carmen; MORILLO CERDÁN, Ángel y GIL SENDINO, Fernando (2012): "El Itinerario de Barro. Cuestiones de autenticidad y lectura". Zhephyrus LXX, pp. 151-179. Recuperado de: https://revistas.usal.es/index.php/0514-7336/article/ view/9332/10351

FRANCISCO OLMOS, José Mạ. (2009): "El Morbo Gothico. La moneda como fuente de estudio de la sucesión al trono en la monarquía visigoda". En VIII Jornadas Científicas sobre Documentación de la Hispania Altomedieval, pp. 119-172. Madrid.
FRANCISCO OLMOS, José Mํ. y VICO MONTEOLIVA, Jesús. (2007): "Historia de la moneda visigoda. Las acuñaciones de la ceca de Toledo". En Hispania Gothorum. San Ildefonso y el Reino Visigodo de Toledo, pp. 181-196. Toledo: Junta de Castilla-La Mancha.

FUENTES DOMÍNGUEZ, Ángel (1989): La necrópolis tardorromana de Albalate de las Nogueras (Cuenca) y el problema de las denominadas "necrópolis del Duero". Cuenca: Diputación de Cuenca.

GARCÍA DE CASTRO, Francisco Javier (1995): Sociedad y Poblamiento en la Hispania del siglo IV d.C. Valladolid.

GARCÍA GONZÁLEZ Juan José y FERNÁNDEZ DE MATA, Ignacio. (1998): "Cantabria transmontana en épocas prerromana y visigoda: perspectivas ecosistémicas". En Iglesia J.I. Duarte (coord.), La vida cotidiana en la Edad Media. VIII Semana de Estudios Medievales, pp. 337-352. Nájera.

GARCÍA MORENO, Luis. A. (2013): España 702-719. La conquista musulmana. Sevilla: Universidad de Sevilla.

GARCÍA Y BELLIDO, Antonio y FERNÁNDEZ DE AVILÉS, Augusto. (1958): Fuentes Tamáricas, Velilla del Río Carrión (Palencia). Madrid: Ministerio de Cultura.

GÓMEZ BARREIRO, Marta (2012): "Circulación monetaria en la Antigüedad en la provincia de Palencia". En Fernández Ibáñez, C., Bohigas Roldán, R. (eds.), en Durii Regione Romanitas. Estudios sobre la Romanización del Valle del Duero en Homenaje a Javier Cortes Álvarez de Miranda, pp. 211-222. Palencia-Santander: Diputación de Palencia e Instituto Sautuola.

GRIERSON, Philip (1993): Catalogue of the Bizantine coins in the Dumbarton Oaks Collection. Vol. 2/1. Washington.

GUTIÉRREZ CUENCA, Enrique (2019): "Ruptura y continuidad. Origen y evolución de los espacios funerarios medievales en el sur de Cantabria". Revista Onoba 7, pp. 113-131. Recuperado de: http:// rabida.uhu.es/dspace/bitstream/handle/10272/16446/ Ruptura.pdf?sequence=2. https://doi.org/10.33776/onoba. v7i0.3627

GUTIÉRREZ CUENCA, Enrique y HIERRO GÁRATE, José Ángel (2007): "El uso de las cuevas de Piélagos entre la época romana y la Edad Media". En Crespo Lastra, V. (coord.), Catálogo de cavidades del municipio de Piélagos. Actuaciones Espeleológicas 1986-2003, pp. 127-137. Santander.

GUTIÉRREZ CUENCA, Enrique y HIERRO GÁRATE, José Ángel (2010): "Instrumentos relacionados con la actividad textil de época tardoantigua y altomedieval en Cantabria”. Munibe 61, pp. 261-288.

GUTIÉRREZ CUENCA, Enrique y HIERRO GÁRATE, José Ángel (20102012): "Nuevas evidencias sobre el uso de las cuevas de Cantabria durante la Tardoantigüedad y la Alta Edad Media. Primeros resultados del Proyecto Mauranus". Sautuola XVI-XVII, pp. 263-280.

GUTIÉRREZ CUENCA, Enrique y HIERRO GÁRATE, José Ángel (2012): "El uso de las cuevas naturales en Cantabria durante la Antigüedad Tardía y los inicios de la Edad Media (siglos V-X)". Kobie 31, pp. 175-206.

GUTIÉRREZ CUENCA, Enrique y HIERRO GÁRATE, José Ángel (2016): "Desenterrando a los últimos visigodos. Actuaciones arqueológicas en Riocueva (2010-2014)". Cantabria. Nuevas evidencias arqueológicas, pp. 155-185. Santander. 
GUTIÉRREZ CUENCA, Enrique y HIERRO GÁRATE, José Antonio (2016b): "Crochets de fuseau en fer du VIIe-VIIIe s. en Cantabrie (ES)". Instrumentum 44, pp. 33-36.

GUTIÉRREZ CUENCA, Enrique y HIERRO GÁRATE, José Antonio, (2016c): "La cerámica de Cantabria entre la Antigüedad Tardía y la Alta Edad Media (siglos V-X)". En A. Vigil-Escalera Guirado, J.A. Quirós Castillo (dir.), La cerámica de la Alta Edad Media en el cuadrante Noreste de la Península Ibérica (siglos V-X). Sistemas de producción, mecanismos de distribución y patrones de consumo, pp. 172-191. Bilbao: Universidad del País Vasco.

GUTIÉRREZ CUENCA, Enrique; HIERRO GÁRATE, José Antonio y ALFARO GINER, Carmen (2014): "Restos textiles de la cueva de Riocueva, Hoznayo (Entrambasaguas, Cantabria)". En Alfaro Giner, C., Tellenbach, M. Ortíz, J. (coords.). Production and trade of textiles and dyes in the Roman Empire and neighbouring regions: Actas del IV Symposium Internacional sobre Textiles y Tintes del Mediterráneo en el mundo antiguo, (Valencia, 5 al 6 de noviembre, 2010), pp. 73-81. Valencia.

GUTIÉRREZ CUENCA, Enrique; HIERRO GÁRATE, José Antonio y PAREDES COURTOT, Helena (2017): "Cerámica común de cocina de los siglos VII-VIII en contexto funerario. La cueva de Riocueva (Cantabria"). Boletín Ex Officina Hispana 8, pp. 100-103.

GUTIÉRREZ CUENCA, Enrique; HIERRO GÁRATE, José Antonio; RÍOS GARAIZAR, Joseba; GÁRATE MAIDAGAN, Diego; GÓMEZ OLIVENCIA, Asier y ARCEREDILLO ALONSO, Diego (2012): El uso de la cueva de Arlampe (Bizkaia) en época tardorromana. Archivo Español de Arqueología 85, pp. 229-251. Recuperado de: http:// aespa.revistas.csic.es/index.php/aespa/article/viewFile/206/207. https://doi.org/10.3989/aespa.085.012.013

GUTIÉRREZ GONZÁLEZ, José Avelino (1982): "Hábitats rupestres altomedievales en la Meseta Norte y Cordillera Cantábrica". Estudios Humanísticos 4, pp. 20-56.

GUTIÉRREZ GONZÁLEZ, José Avelino (2010): "Arqueología tardoantigua en Asturias. Una perspectiva de la organización territorial y del poder en los orígenes del Reino de Asturias". En J.I. Ruiz de la Peña Solar y J. Camino Mayor (coords.), La Carisa y La Mesa. Causas políticas y militares del origen del Reino de Asturias, pp. 53-83. Oviedo: Asociación de Amigos de La Carisa.

GUTIÉRREZ GONZÁLEZ, José Avelino (2019): "Sobre la conquista islámica del Noroeste peninsular. Recientes aportaciones”. En C. Fernández Ibáñez (ed.), AL-KITAB Juan Zozaya Stabel-Hansem, pp. 261-267. Madrid: Asociación Española de Arqueología Medieval.

GUTIÉRREZ GONZÁLEZ, José Avelino e IBÁÑ̃EZ CALZADA, Covadonga. (2003): "Industria ósea". En J.A. Gutiérrez González (ed.), Peñaferruz (Gijón). El Castillo de Curiel y su Territorio, pp. 279-288. Gijón: Ayuntamiento de Gijón, vtp editorial.

HALL, Richard (1995): Viking Age Archaeology. Oxford: Shire.

HERNÁNDEZ GUERRA, Liborio (1994): Inscripciones romanas en la provincia de Palencia. Valladolid: Universidad de Valladolid.

HERNÁNDEZ GUERRA, Liborio y SAGREDO SAN EUSTAQUIO, Luis (1998): La romanización del territorio de la actual provincia de Palencia. Valladolid: Universidad de Valladolid.

HERRÁEZ MARTíN, Mํㅡㄴ Isabel (2017): "El peine de Castiltierra”. En I. Arias Sánchez y L.J. Balmaseda Muncharaz (coords.), Excavaciones dirigidas por E. Camps y J.Mํ. de Navascués, 1932-1935. Materiales conservados en el Museo Arqueológico Nacional. Tomo II: Estudios, pp. 242-253. Madrid: Ministerio de Educación, Cultura y Deporte.

HIERRO GÁRATE, José Antonio (2011): "La utilización de las cuevas en época visigoda: los casos de Las Penas, La Garma y el Portillo del Arenal (Cantabria)". Munibe 62, pp. 351-402.

HIERRO GÁRATE, José Antonio (2017): "Un terminal de cinturón altomedieval de la cueva del Aspio (Ruesga, Cantabria)". Pyrenae 48 (1), pp. 137-156.

HIERRO GÁRATE, José Antonio y MARTínEZ VELASCO, Antxoka (2016): "Cueva de Astillo, San Martín de Elines, Valderredible". Área 4, pp. 389-394.

IGLESIAS GIL, José Manuel y MUÑIZ CASTRO, Juan Antonio (1992): Las comunicaciones en la Cantabria romana. Santander: Universidad de Cantabria y Librería Estudio.

JIMENO GUERRA, Vanessa (2018): "Nuevas aportaciones a los estudios sobre el uso de cavidades naturales durante la Edad Media en la provincia de León". Territorio, Sociedad y Poder, 13, pp. 49-70. Recuperado de: https://www.unioviedo.es/reunido/ index.php/TSP/article/view/11409/11960. https://doi. org/10.17811/tsp.13.2018.49-70

JIMÉNEZ DE RADA, Rodrigo, (1989): De Rebus Hispaniae (Introducción, notas e índices J. Ferández Valverde). Madrid. Alianza Ed.

JONSON, Thomas (2014): A Numismatic History of the Early Islamic Precious Metal Coinage of North Africa and the Iberian Peninsula. Oxford.

LECANDA, José Ángel (2015): Estudio arqueológico del Desfiladero de La Horadada: La transición entre la tardorromanidad y la Alta Edad Media (ss. V-X d.n.e.). Memoria para el Grado de Doctor. Universidad de Burgos. Recuperada de: http://hdl.handle. net/10259/4641.

LÓPEZ-MONDÉJAR, Leticia (2009): "Las cuevas con ocupación romana en el Noroeste murciano: Definición e interpretación”. Sagvntvm 41, pp. 209-220.

LOSTAL PROS, Joaquín (1992): Los miliarios de la Tarraconense. Zaragoza: Institución Fernando el Católico.

LUIS MARIÑO, Susana de (2014): "Aproximación al uso de las cuevas en la Edad del Hierro: el caso del Cantábrico Centro-Oriental (Península Ibérica)". Munibe 65, pp. 137-156. https://doi. org/10.21630/maa.2014.65.09

MACHAUSE LÓPEZ, Sonia (2019): Las cuevas como espacios rituales en época ibérica. Los casos de Kelin, Edeta y Arse. Jaén: Universidad de Jaén.

MAílLO SALGADO, Felipe (2011): Acerca de la conquista árabe de Hispania. Imprecisiones, equívocos y patrañas. Gijón: Trea.

MAÑANES PÉREZ, Tomás y SOLANA SAINZ, José Ma․ (1985): Ciudades y vías romanas en la cuenca del Duero (Castilla y León). Valladolid: Universidad de Valladolid.

MAROT, Teresa (2001): "La Península Ibérica en los siglos V-VI: consideraciones sobre previsión, circulación y usos monetarios". Pyrenae 31-32, pp. 133-160 
MARTIN, Kathleen (ed.) (2011): El libro de los símbolos. Reflexiones sobre las imágenes arquetípicas. Madrid: Taschen.

MARTÍN ESQUIVEL, Alberto (2018): "La moneda en los siglos IV-VIII d.C.: tipos, función y usos monetarios". En Fortificaciones, Poblados y Pizarras. La Raya en los inicios del Medievo, pp. 263-275. Ciudad Rodrigo: Ayuntamiento de Ciudad Rodrigo.

MARTÍN-ESQUIVEL, Alberto y BLÁZQUEZ-CERRATO, Cruces. (2018): "Hallazgos monetarios en el área lusitana situada entre el Duero y el Tajo (siglos IV-VIII)". Conimbriga 57, pp. 139-168. https://doi. org/10.14195/1647-8657_57_4

MARTín GUTIÉRREZ, Carmen (2000): "Industria ósea y otros materiales". En M.A. García Guinea (dir.), La villa romana de Quintanilla de la Cueza (Palencia). Memoria de las excavaciones 1970-1981, pp. 201-210. Salamanca: Junta de Castilla y León.

MARTíN ORTEGA, Ricardo (1998): "La Chronica Naierensis: Acerca de su toponimia”. Habis, 29, pp. 307-322.

MARTíN VISO, Iñaki (2008): "Tremisses y potentes en el nordeste de Lusitania (siglos VI-VII)". Mélanges de la Casa de Velázquez 38 (1), pp. 175-200. Recuperado de: https://journals.openedition.org/mcv/1017.

MARTín VISO, Iñaki (2013): "Prácticas locales de la fiscalidad en el reino de Toledo". En X. Ballestín, E. Pastor (eds.), Lo que vino de Oriente. Horizontes, praxis y dimensión material de los sistemas de dominación fiscal en Al-Andalus (ss. VII-IX), pp. 72-85. Oxford: Archeopress. https://doi.org/10.4000/mcv.1017

MARTíN VISO, Iñaki (2016): Asentamientos y paisajes rurales en el occidente medieval. Madrid: Síntesis.

MARTÍNEZ CHICO, David y GONZÁLEZ GARCÍA, Alberto (2017): "Nuevos hallazgos monetales visigodos. Oro y bronce en el Norte de Cáceres". Habis 48, pp. 291-315.

MARTÍNEZ PIZARRO, Joaquín (2005): The History of Wamba. Juliano of Toledo's Historiae Wambae regis. Translated with an introduction and Notes by J. Martínez Pizarro. Whasington.

MATEOS CACHORRO, Ana; RODRÍGUEZ MÉNDEZ, Jesús. (2017): Memoria de las intervenciones arqueológicas Cueva de Guantes. Expte: 5/2016-PA. Burgos: CENIEH (inédito).

MATEOS CACHORRO, Ana; RODRÍGUEZ MÉNDEZ, Jesús. (2017b): Memoria de las intervenciones arqueológicas Cueva de Guantes. Expte: 14/2017-PA. Burgos: CENIEH (inédito).

MATEOS, Ana; RODRÍGUEZ, Jesús; LAPLANA, César; SEVILLA, Paloma; OLLÉ, Andreu; KARAMPAGLIDIS, Theodoros; RODRÍGUEZ-GÓMEZ, Guillermo. (2014): "Los yacimientos arqueo-paleontológicos de La Loma y el poblamiento paleolítico del norte de Palencia". Colección de Historia Montaña Palentina, 8, 11-44.

MAYA GONZÁLEZ, José Luis y CUESTA TORIBIO, Francisco (2001): El Castro de la Campa Torres. Período Prerromano. Gijón: Ayuntamiento de Gijón y vtp editorial.

MEDIAVILLA DE GALA, Luis Manuel (2011): "San Román de Entrepeñas: nuevos datos sobre este primitivo monasterio". Colección de Historia de la Montaña Palentina 5, pp. 79-96.

METCALF, Michael (1986): "Some Geographical Aspects of Early Medieval Monetary Circulation in the Iberian Peninsula". En M.
Gomes Marques y M. Crusafont (eds.), Problems of Medieval Coinage in the Iberian Area, II, pp. 310-315. Madrid.

MERQUÍRIZ IRUJO, Mạ. Ángeles (2009): "Producción artesanal romana: objetos de hueso encontrados en yacimientos navarros". Trabajos de Arqueología Navarra 21, pp. 161-198. Recuperado de: https://dialnet.unirioja.es/servlet/articulo?codig $\mathrm{o}=3126832$.

MILES, G.C. (1952): The Coinage of The Visigoths of Spain Leovigild to Achila Il. New York

MÍNGUEZ ÁVARO, Mํ. Teresa y LOPES SOUSA, Rui Manuel (2012): "La TSHT procedente de "El Portalón" de Cueva Mayor de Atapuerca (Burgos). Campañas de Excavación 1973-83”. En Fernández Ibáñez, C., Bohigas Roldán, R. (eds.), en Durii Regione Romanitas. Estudios sobre la Romanización del Valle del Duero en Homenaje a Javier Cortes Álvarez de Miranda, pp. 405-409. Palencia-Santander: Diputación de Palencia e Instituto Sautuola.

MÍNGUEZ FERNÁNDEZ, José Mํ. (1976): Colección diplomática del Monasterio de Sahagún (siglos IX XX). León: Centro de Estudios San Isidoro.

MOLINA, Monserrat (1995): "Las tierras de Palencia durante la monarquía goda”. En J. González (ed.), Historia de Palencia. Volumen I. Edades Antigua y Media, pp. 129-153. Palencia: Diputación Provincial de Palencia.

MORENO GALLO, Isaac (2001): Descripción de la vía romana de Italia a Hispania en las provincias de Burgos y Palencia. Burgos: Diputación de Burgos.

MORONI, M.T. (2013): "Oggetti in osso e avorio". A. Capodiferro (ed.), Museo Nazionale Romano. Evan Gorga. La Collezione di Archeologia, pp. 226-242. Milano: Electa.

MOYA MALENO, Pedro Reyes (2008): "Ager y afiladeras: Dos hitos en el estudio de municipio laminitano (Alhambra, Ciudad Real)". En J. Mangas, M.A. Novillo (eds.), El territorio de las ciudades romanas, pp. 557-588. Madrid: Sísifo.

MUÑIZ CASTRO, Juan Antonio (1999): "Articulación del espacio en la Cantabria prerromana y romana: red viaria y territorio". En I Encuentro de Historia de Cantabria: Actas del encuentro celebrado en Santander los días 16 a 19 de diciembre de 1996. Vol. 1, 1990, pp. 291-306. Santander.

MUÑOZ ROMERO, Tomás (1847): Colección de Fueros Municipales y Cartas Pueblas de los Reinos de Castilla, León, Corona de Aragón y Navarra. Tomo I. Madrid (edición facsimilar Valladolid, 2000: Lex Nova).

NIETO BALlESTER, Emilio (2000): "La toponimia de las fuentes en España: Una nota sobre algunos resultados del lat. Fonte". Revista de Filología Española LXXX, $3^{\circ}-4^{\circ}$, pp. 395-406. Recuperado de : http://xn--revistadefilologiaespaola-uoc.revistas. csic.es/index.php/rfe/article/view/267/270. https://doi. org/10.3989/rfe.2000.v80.i3/4.267

NIETO BALLESTER, Emilio (2013): "Falsos antropónimos en la toponimia española: Fuente de Mariguantes, Alto de Maripez, Mariagua". Revista de Filología Española XCIII, 2², pp. 327-335. Recuperado de: https://repositorio.uam.es/bitstream/ handle/10486/664940/falsos nieto rfges 2013.pdf?sequence=1. https://doi.org/10.3989/rfe.2013.12 
NUÑO GONZÁLEZ, Jaime (1991): "Poblamiento de época romana en el valle de La Ojeda (Palencia)". II Congreso de Historia de Palencia, pp. 245-273. Palencia: Diputación de Palencia.

OCEJO HERRERO, Ángel; BOLADO DEL CASTILLO, Rafael; GUTIÉRREZ CUENCA, Enrique; HIERRO GÁRATE, José Ángel y CABRIA GUTIÉRREZ, Juan Carlos (2012): Cántabros. Origen de un pueblo. Santander: Asociación para la Defensa de los Intereses de Cantabria.

ORLANDIS, José (1977): La España Visigótica. Gredos: Madrid.

ORTEGA ORTEGA, Julián M. (2018): La conquista islámica de la península ibérica. Una perspectiva arqueológica. Madrid: La Ergástula.

PALOL, Pedro del (1970): Castilla la Vieja entre el Imperio Romano y el Reino Visigodo. Valladolid: Universidad de Valladolid. Recuperado de: https://uvadoc.uva.es/bitstream/handle/10324/4124/Disc.Apert.UVA1970-71. pdf? sequence $=1 \&$ isAllowed $=y$.

PERALTA LABRADOR, Eduardo (2003): Los cántabros antes de Roma. Madrid: Real Academia de la Historia.

PÉREZ-ALMOGUERA, Arturo; RAFEL FONTANALS, Nuria; ARILLA OSUNA, Maite y CARRERAS ROSSELL, Teresa (2011): "La ocupación prehistórica y romana de la cavidad M35 del baix Pallars (Pallars Sobirà, Lleida)". Revista d'Arqueologia de Ponent 21, pp. 103-118. Recuperado de: http://www.rap.udl.cat/export/sites/ Arqueologia/ca/.galleries/Documents/22.5-Perez-et-al.. pdf.

PÉREZ RODRÍGUEZ-ARAGÓN, Fernando (1996): "La cultura de Tchernjahov, la diáspora gótica y el peine de Cacabelos". Boletín del Seminario de Estudios de Artey Arqueología 62, pp. 173-184.

PETITEJEAN, Michel (1995): "Les peignes en os à l'époque mèrovingienne. Évolution depuis l'Antiquité tardive". Antiquites Nationales 27, pp. 145-191.

PICOD, Christophe; RODET-BELARBI, Isabel y CHÂTELET, Madeleine (2016): "La fabrication des peignes en bois de cerf et en os de I'Antiquité tardive et du haut Moyen Age: étude tracéologique et expérimentation sur les peignes d'Obernai et de Marlenheim (BasRhin, FR)". Instrumentum 44, pp. 36-45. Recuperado de: https:// hal-inrap.archives-ouvertes.fr/hal-01716826/document.

PINAR, Joan y TURELL, Luis (2007): "Ornamenta uel uestimenta ex sepulchro abstulere. Reflexiones en torno a la presencia de tejidos, adornos y accesorios de indumentaria en el mundo funerario del Mediterráneo tardoantiguo". Collectanea Christiana Orientalia 4, pp. 127-167. Recuperado de: www.uco.es > revistas > index.php > cco > article > download. https://doi.org/10.21071/cco.v4i.84

PLIEGO VÁZQUEZ, Ruth (2009): La moneda visigoda. Historia del monetario del reino de Toledo (c. 569-711). 2 Vols. Sevilla: Universidad de Sevilla.

PLIEGOVÁZQUEZ, Ruth (2012): "La monedavisigoda:Anexo I". Spal21, pp. 209-231. Recuperado de: https://idus.us.es/handle/11441/ 34411;jsessionid=FF8289800208ED3A24174942C6D47693? .https://doi.org/10.12795/spal.2012i21.12

PLIEGO VÁZQUEZ, Ruth (2015): "El tremís de los últimos años del Reino Visigodo (702-714)”. En Sénac, Ph., Gasc, S. (éds.), Monnaies du haut Moyen Âge: histoire et archeology (peninsula Ibérique-Maghreb, VIle-Xle siècle). Villa 5, pp. 17-58. Toulouse: Presses universitarires du Midi Université Toulouse-Jean Jaurès. https://doi. $\operatorname{org} / 10.4000 /$ books.pumi.16822

PLIEGO VÁZQUEZ, Ruth (2020): "Visigothic Currency: Recent Developments and Data for Its Study”. En E. Dell'Elicine, C. Martin (eds.), Framing Power in Visigothic Society. Discourses, Devices and Artefacts, pp. 181-215. Amsterdam: Amsterdam University Press. https://doi.org/10.2307/j.ctvw1d4xc.11

POVEDA ARIAS, Pablo (2015): "Relectura de la supuesta crisis del fin del reino visigodo de Toledo: una aproximación al reinado de Égica a través de sus fuentes legales". Anuario de Historia del Derecho Español LXXXV, pp. 13-46. Recuperado de: https://dialnet. unirioja.es/servlet/articulo?codigo $=5712555$.

QUINTANA LÓPEZ, Javier (2008): "Amaya, ¿Capital de Cantabria?". En J.R. Aia Sánchez, M. Cisneros Cunchillos, J.L. Ramírez Sádaba (coords.), Los cántabros en la antigüedad: la historia frente al mito, pp. 229-264. Santander: Universidad de Cantabria.

QUINTANA LÓPEZ, Javier (2017): El Castro de Peña Amaya (Amaya, Burgos): del Nacimiento de Cantabria al de Castilla. Santander: Comunidad de Cantabria.

QUIRÓS CASTILLO, Juan Antonio y ALONSO MARTíN, A. (20072008): "Las ocupaciones rupestres en el fin de la Antigüedad. Los materiales cerámicos de Los Husos (Laguardia, Álava)". Veleia 24-25, pp. 1123-1142. Recuperado de: https://www.ehu.eus/ ojs/index.php/Veleia/article/view/2123.

RAPOSO, Luis; SANTOS, Ana Isabel; ALARCÂO, Adilia; ALVES DIAS, M. Manuela; PARREIRA, Rui; COELHO, Luis; FARIA, Antonio; NOLEN, Jeannette; ARAUD, José y MARTINS, Manuela (1989): Museu Nacional de Arqueologia e Etnologia. Le Portugal Des Origines à l'Epoque Romaine. Lisboa: Instituto Portugués do Património Cultural.

RÉCHIN, François y DUMONTIER, Patrice (2013): "Une grotte pyrénéenne occupée au début de l'époque romaine: le site d'Apons à Sarrance (Pyrénées-Atlantiques)". En D. Barraud, F. Réchin (eds.), D'lluro à Oloren-Sainte-Marie, Un millénaire d'histoire, pp. 97-143. Burdeos. Recuperado de: https://www.persee.fr/doc/ bspf_0249-7638_1999_num_96_3_11216. https://doi. org/10.3406/bspf.1999.11216

REGUERAS GRANDE, Fernando y RODRÍGUEZ CASANOVA, Isabel. (2017): "Triente de Sisebuto y dinar de indicción en dos villae romanas leonesas". Brigecio 27, pp. 11-24.

REQUEJO PAGÉS, Otilia (2018): "La expresión arqueológica del mundo funerario en Asturias en la romanidad tardía: cementerios, difuntos y ritos". En M.A. De Blas Cortina (ed.), Arqueología de época histórica en Asturias, pp. 69-104. Oviedo: RIDEA.

RETAMERO, Félix (2011): "La moneda del Regnum Gothorum (ca. 575-714). Una revisión del registro numismático". En Díaz, P.C., Martín Viso, I. (eds.), Between Taxation and Rent. Fiscal problems from Late Antiquity to Early Middle Ages, pp. 189-220. Bari: Edipuglia.

REVUELTA CARBAJO, Raúl (1997): La ordenación del territorio en Hispania durante la tardoantigüedad tardía. Estudio y selección de textos. Madrid: Universidad Complutense.

RIJKELIJKHUIZEN, Marloes (2011): "Dutch medieval bone and antler combs". En J. Baron, B. Kufel-Diakowska (eds.), Written in Bones. 
Studies on technological and social contexts of past faunal skeletal remains, pp. 197-206. Wroclaw.

RODRÍGUEZ, Jesús; MATEOS, Ana. (2014): "La acumulación de osos de las cavernas (Ursus Spelaeus, Rossenmüller-Heinroth) de la Cueva de Guantes (Palencia)". Sautuola 19, 547-554.

ROLDÁN HERVÁS, Jose Mạ (1975): Itineraria hispana: fuentes antiguas para el estudio de las vías romanas en la Península ibérica. Valladolid-Granada.

ROLFE, John (1950): Ammianus Marcellinus, History. Volumen I. Books 14-19. Cambridge, Massachusetts-London: Harvard University Press.

ROMERO SUÁREZ, Margarita (2003): "Material lítico". En J.A. Gutiérrez González (ed.), Peñaferruz (Gijón). El Castillo de Curiel y su Territorio, pp. 257-267. Gijón: Ayuntamiento de Gijón, vtp editorial.

RUBIO VALVERDE, Manuel (2014): "Vestigios de ocupación romana en cuevas naturales de la Subbética Cordobesa. Nuevas hipótesis interpretativas". Antiquitas26, pp. 205-225. Recuperadode:https:// webcache.googleusercontent.com/search?q=cache:UCRdFOzD1j8J:https://dialnet.unirioja.es/descarga/articulo/4990981.pdf+\&cd=1\&hl=es\&ct=clnk\&gl=es.

RUESGA HERREROS, Laurentino (2007): "Por la Cantabria romana. De Vellica a Camarica". Altamira: Revista del Centro de Estudios Montañeses 71, pp. 29-40.

RUIZ TRAPERO, María (2004): "En torno a la moneda visigoda". Documenta \& Instrumenta 1, pp. 179-201. Recuperado de: https://revistas.ucm.es/index.php/DOCU/article/view/ DOCU0404110179A.

RUSTICO, L. (2013): "Pesi da telaio". En A. Capodiferro (ed.), Museo Nazionale Romano. Evan Gorga. La Collezione di Archeologia, pp. 220-225. Milano: Electa.

SALES CARBONELL, Jordina (2012): Las construcciones cristianas de la Tarraconensis durante la Antigüedad Tardía. Topografía, arqueología e historia. Barcelona: Universidad de Barcelona.

SALVATIERRA, Vicente y CANTO, Alberto (2008): Al-Ándalus. De la invasión al Califato de Córdoba. Madrid: Síntesis.

SÁNCHEZ ALBORNOZ, Claudio (1972): Orígenes de la Nación Española. El Reino de Asturias. Tomo I. Oviedo: IDEA.

SÁNCHEZ BELDA, Luis (1948). Cartulario de Santo Toribio de Liébana. Madrid: CSIC.

SÁNCHEZ-PALENCIA, F. Javier y FERNÁNDEZ-POSSE, Ma․ Dolores (1985): La Corona y el Castro de Corporales I. Truchas (León). Campañas de 1978 a 1981. Madrid: Ministerio de Cultura.

SÁNCHEZ PARDO, José Carlos (2014): "Sobre las bases económicas de las aristocracias en la Gallaecia suevo-visigoda (ca. 530650 D.C.)". Anuario de Estudios Medievales 44 (2), pp. 983-1023. Recuperado de: http://estudiosmedievales.revistas.csic. es/index.php/estudiosmedievales/article/view/733/747. https://doi.org/10.3989/aem.2014.44.2.10

SANTONJA GÓMEZ, Manuel; SANTONJA ALONSO, Manuel y ALCALDE CRESPO, Gonzalo (1982): "Aspectos de la ocupación humana antigua del cañón de La Horadada (Palencia)". Publicaciones de la Institución Tello Téllez de Meneses, 47, pp. 159-200.
SANZ MÍNGUEZ, Carlos; ROMERO CARNICERO, Fernando; GÓRRIZ GAÑÁN, Cristina y DE PABLO MARTÍNEZ, Roberto (2011): "El foso y el sistema defensivo de Pintia (Padilla de Duero/Peñafiel, Valladolid)". Revista d'Arqueologia de Ponent, 21, pp. 221-232.

SCHULTEN, Adolf (1943): Los Cántabros y Astures y su guerra con Roma. Madrid: Espasa Calpe.

SÉNAC, Philippe; GASC, Sébastien; MELMOUX, Pierre.-Yves y SAVARESE, Laurent (2014): "Noveaux vestiges de la présence musulmane en Narbonnaise au VIII siècle". Al-Qantara, XXXV (1), pp. 61-94. https://doi.org/10.3989/alqantara.2014.003

SMITH, Peter y MUÑOZ FERNÁNDEZ, Emilio (2010): "Las Cuevas de la Edad del Hierro en Cantabria”. En M.L. Serna Gancedo, A. Martínez Velasco y V. Fernández Acebo (coords.), Castros y Castra en Cantabria. Fortificaciones desde los orígenes de la Edad del Hierro a las guerras con Roma. Catálogo, revisión y puesta al día, pp. 576693. Santander: Acanto.

SOLANA SAINZ, José María (1973): Los Tvmorgos durante la época romana. Valladolid: Universidad de Valladolid.

SOLANA SAINZ, José María (1974): Los Autrigones a través de las fuentes literarias. Álava: Universidad de Valladolid.

SOLANA SAINZ, José María (1981): Los cántabros y la ciudad de Iuliobriga. Santander: Librería Estudium.

STOLL, Hermann (1939): Die Alamannengräber von Hailfingen in Württenmberg: Germanische Denkmäler der Völkerwanderungszeit. Berlín.

TEJERIZO GARCÍA, Carlos (2017): Arqueología de las sociedades campesinas en la cuenca del Duero durante la primera Alta Edad Media. Bilbao: Universidad del País Vasco.

TOBALINA PULIDO, Leticia; CAMPO, Alain; DUMÉNIL, Vincent y PACE, Beniot (2016): "Historiografía, metodología y problemática en el estudio de la frecuentación de las cuevas naturales en época romana entre el Ebro y el Garona". Antesteria 5, pp. 197-206. Recuperado de: https://www.ucm.es/data/cont/docs/1062017-05-02-13.\%20TOBALINA,\%20CAMPO,\%20DUM\%C3\%89NIL\%20y\%20PACE.pdf.

TOVAR. Antonio (1989): Iberische Landeskunde. Tomo 3. Tarraconensis. Baden-Baden: Verlag Valentin Koerner.

VALVERDE CASTRO, Rosario (2007): "Monarquía y tributación en la Hispania visigoda: el marco teórico". Hispania Antiqvua 31, pp. 235-251. Recuperado de: https://dialnet.unirioja.es/servlet/ articulo? codigo $=2660670$.

VALVERDE CASTRO, Rosario (2017): Los viajes de los reyes visigodos de Toledo (531-711). Madrid: La Ergástula.

VERARODRÍGUEZ, Juan Carlos (1991): "Materiales delacuevadela Mina de Jarcas (Cabra, Córdoba)". Antiqvitas 2, pp. 62-68. Recuperado de: https://dialnet.unirioja.es/servlet/articulo?codigo=271730.

VERA RODRÍGUEZ, Juan Carlos (1994): "Un nuevo testimonio arqueológico sobre la presencia efectiva de contingentes centroeuropeos en la Hispania bajoimperial: una hebilla de cingulum militia procedente del Sur de Córdoba". Antiqvitas 5, pp.69-71. Recuperado de: https://dialnet.unirioja.es/servlet/ articulo? codigo $=272639$. 
VICO MONTEOLIVA, Jesús; CORES GOMENDIO, Mạ. Cruz y CORES URÍA, Gonzalo (2006): Corpus Nummorum Visigothorum. Ca. 575714. Leovigildus-Achila. Madrid: Autoedición.

VINGO, Paolo de (2018): "The occupation and use of natural caves in the Ligurian-Piedmontese region between Late Antiquity and the Early Middle Ages (fifth to late seventh century AD)". En K.A. Bergsviky M. Dowd (eds.), Caves \& Ritual in Medieval Europe, AD 5001500, pp. 165-184. Oxford: Oxbow. https://doi.org/10.2307/j. ctvh1dnwt.14
VITEZOVIC, Selena (Ed.) (2016): Close to the Bone. Current Studies in Bone Technologies. Belgrade: Institute of Archaeology Belgrade.

WATTENBERG, Federico (1983): Excavaciones en Numancia, Campaña de 1963. Valladolid: Museo Arqueológico de Valladolid.

WOJENKA, Michal (2018): "Knihts in the Dark: on the function of Polish caves in the Middle Ages". En K.A. Bergsviky M. Dowd (eds.), Caves \& Ritual in Medieval Europe, AD 500-1500, pp. 232-246. Oxford: Oxbow. https://doi.org/10.2307/j.ctvh1dnwt.18 